\title{
Altered Cerebellar Short-Term Plasticity but No Change in Postsynaptic AMPA-Type Glutamate Receptors in a Mouse Model of Juvenile Batten Disease
}

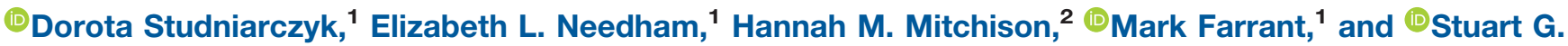 \\ Cull-Candy ${ }^{1}$
}

\section{DOI:http://dx.doi.org/10.1523/ENEURO.0387-17.2018}

${ }^{1}$ Department of Neuroscience, Physiology and Pharmacology, University College London, London WC1E 6BT, United Kingdom and ${ }^{2} \mathrm{UCL}$ Great Ormond Street Institute of Child Health, University College London, London WC1N 1EH, United Kingdom

\begin{abstract}
Juvenile Batten disease is the most common progressive neurodegenerative disorder of childhood. It is associated with mutations in the CLN3 gene, causing loss of function of CLN3 protein and degeneration of cerebellar and retinal neurons. It has been proposed that changes in granule cell AMPA-type glutamate receptors (AMPARs) contribute to the cerebellar dysfunction. In this study, we compared AMPAR properties and synaptic transmission in cerebellar granule cells from wild-type and Cln3 knock-out mice. In $C \ln 3^{\Delta e x 1-6}$ cells, the amplitude of AMPA-evoked whole-cell currents was unchanged. Similarly, we found no change in the amplitude, kinetics, or rectification of synaptic currents evoked by individual quanta, or in their underlying single-channel conductance. We found no change in cerebellar expression of GluA2 or GluA4 protein. By contrast, we observed a reduced number of quantal events following mossy-fiber stimulation in $\mathrm{Sr}^{2+}$, altered short-term plasticity in conditions of reduced extracellular $\mathrm{Ca}^{2+}$, and reduced mossy fiber vesicle number. Thus, while our results suggest early presynaptic changes in the $C / n 3^{\Delta e \times 1-6}$ mouse model of juvenile Batten disease, they reveal no evidence for altered postsynaptic AMPARs.
\end{abstract}

Key words: AMPA receptors; Batten disease; cerebellum; CLN3; EPSCs; short-term plasticity

\section{Significance Statement}

Juvenile Batten disease is an inherited lysosomal storage disorder that affects children and leads to premature death. Caused by mutations in the CLN3 gene, it results in a loss of CLN3 protein and neuronal degeneration. It has been proposed that changes in granule cell AMPA-type glutamate receptors (AMPARs) contribute to cerebellar dysfunction. Here, we show that the properties of postsynaptic AMPA receptors in granule cells from juvenile $\mathrm{Cln} 3^{\Delta e x 1-6}$ mice are unaltered. Instead, loss of CLN3 protein leads to early presynaptic changes and altered short-term plasticity.

\section{Introduction}

Batten disease is the collective term for a group of rare inherited neurodegenerative disorders, the neuronal ceroid

Received November 15, 2017; accepted March 27, 2018; First published April 20, 2018.

The authors declare no competing financial interests. lipofuscinoses (NCLs). These result from mutations in one of 14 ceroid-lipofuscinosis, neuronal type (CLN) genes (Cotman et al., 2013; Mole and Cotman, 2015; Nita et al., 
2016), the majority of which encode soluble lysosomal enzymes or lysosome-associated transmembrane proteins (Cárcel-Trullols et al., 2015). The most common NCL is juvenile CLN3 disease or juvenile Batten disease (Williams and Mole, 2012). Children with this condition first exhibit symptoms at four to seven years of age, suffer loss of vision, seizures, progressive motor and cognitive decline, and die prematurely in late adolescence (Munroe et al., 1997; Haltia, 2003).

Juvenile Batten disease is caused by mutations in the CLN3 gene, commonly a 1-kb deletion encompassing exons 7 and 8 , that result in the loss of full-length CLN3 protein (The International Batten Disease Consortium, 1995; Munroe et al., 1997; Kitzmüller et al., 2008). Like other NCLs, juvenile Batten disease is considered a lysosomal storage disorder and is characterized by the accumulation within lysosomes of autofluorescent lipopigments (lipofuscin-like ceroid; Seehafer and Pearce, 2006). Although the precise function of CLN3 remains unresolved, it has been implicated in multiple cellular phenomena, including endocytosis and endocytic trafficking, lysosmal $\mathrm{pH}$ regulation, autophagy, proliferation, cell-cycle control, and apoptosis (Cárcel-Trullols et al., 2015).

Cerebellar atrophy is a feature of juvenile Batten disease (Nardocci et al., 1995; Autti et al., 1996) and likely contributes to the eventual motor deficits (Raininko et al., 1990). Likewise, in mouse models of the disease, there are degenerative changes and neuronal loss in the cerebellum, seen most clearly in CLN3 knock-out animals (designated $\mathrm{Cln} 3^{\Delta e \times 1-6}$ or $\mathrm{Cln3}^{-/}$; Kovács et al., 2006; Weimer et al., 2009) but also evident in mice with knock-in of the most common human 1-kb deletion mutation (C/n3 ${ }^{\operatorname{sex} 7 / 8}$; Cotman et al., 2002).

Several studies have provided evidence of a change in neuronal AMPA-type glutamate receptors (AMPARs) in juvenile Batten disease. Thus, in $\mathrm{C} / n 3^{\Delta e x 1-6}$ and $\mathrm{C} / n 3^{\Delta e x 7 / 8}$ mice, cerebellar granule cells - neurons in the cerebellum that relay multisensory and motor-related information from mossy fibers to Purkinje cells (Eccles et al., 1967; Huang et al., 2013; Chabrol et al., 2015) - are reported to exhibit increased susceptibility to excitotoxic damage following activation of AMPARs (Kovács et al., 2006; Finn et al., 2011). These receptors, mediate a majority of fast excitatory transmission in the brain, and function as homo- or hetero-tetrameric assemblies of pore-forming subunits (GluA1-4; Traynelis et al., 2010). Although most AMPARs

This work was supported by Medical Research Council (MRC) Grants MR/ J002976/1 (to S.G.C.-C. and M.F.) and MR/J012998/1 (to M.F. and S.G.C.-C.) and by the Wellcome Trust Grant $086185 / Z / 08 / Z$ (to S.G.C.-C. and M.F.). E.L.N. was supported by the BBSRC Studentship BB/D526961/1.

Acknowledgements: We thank Mark Turmaine, Steve Sullivan, and Marzieh Zonouzi for valuable discussions and help.

Correspondence should be addressed to either of the following: Stuart G. Cull-Candy at the above address, E-mail: s.cull-candy@ucl.ac.uk; or Mark Farrant at the above address, E-mail: m.farrant@ucl.ac.uk.

DOI:http://dx.doi.org/10.1523/ENEURO.0387-17.2018

Copyright (C) 2018 Studniarczyk et al.

This is an open-access article distributed under the terms of the Creative Commons Attribution 4.0 International license, which permits unrestricted use, distribution and reproduction in any medium provided that the original work is properly attributed. in the central nervous system contain the edited GluA2(R) subunit, and are thus calcium impermeable (Cl-AMPARs), those lacking GluA2 constitute a widely distributed subtype of calcium permeable AMPARs (CP-AMPARs; Burnashev et al., 1992; Geiger et al., 1995; Cull-Candy et al., 2006).

Excess influx of $\mathrm{Ca}^{2+}$ through CP-AMPARs appears to be a feature common to several neurodegenerative disorders, including stroke, motor neuron disease, and hypoxic ischemic white matter damage (Follett et al., 2000; Kawahara and Kwak, 2005; Noh et al., 2005; Van Den Bosch et al., 2006; Corona and Tapia, 2007). Increased AMPAR-mediated excitotoxicity in $C / n 3^{\Delta e x 1^{-6}}$ mice has been suggested to reflect altered AMPAR trafficking, an increase in CP-AMPAR number and enhanced AMPAR function (Kovács et al., 2006). However, recent experiments have described an increase in GluA2 protein in the cerebellum of $C / n 3^{\Delta e \times 1-6}$ mice (Kovács et al., 2015), a change which is more usually associated with increased prevalence of Cl-AMPAR subtypes.

Here, we have compared AMPAR properties and excitatory synaptic transmission in cerebellar granule cells from wild-type and $C / n 3^{\Delta e \times 1-6}$ mice. Our results suggest that loss of CLN3 results in altered mossy-fiber presynaptic behavior but no alteration in postsynaptic AMPAR function and no increase in CP-AMPAR prevalence.

\section{Materials and Methods}

\section{Animals}

We used wild-type C57BL/6 J mice and C/n3 knock-out mice $\left(\mathrm{C} / n 3^{\Delta e x 1-6}\right)$ on a C57BL/6J background. $C / n 3^{\Delta e x 1-6}$ mice were generated via targeted disruption of the $\mathrm{Cln} 3$ gene involving the deletion of exons 2-6 and most of exon 1 via replacement with a neomycin resistance gene that was transcribed in reverse orientation from a mouse PGK promoter (Mitchison et al., 1999). Both male and female mice were used. All procedures for the care and treatment of mice were in accordance with the Animals (Scientific Procedures) Act 1986.

\section{Western blotting}

Cerebellar tissue was homogenized in RIPA lysis buffer with proteinase inhibitors (Roche). Protein extracts were boiled for $5 \mathrm{~min}$ at $95^{\circ} \mathrm{C}$ before loading onto $5-10 \%$ gradient gels (50 $\mu \mathrm{g}$ of protein sample per lane). Gels were electrotransferred to a $0.2-\mu \mathrm{m}$ nitrocellulose membrane (GE Healthcare). Blots were blocked in $4 \%$ milk (wt/vol) in PBSTween 20 solution for $1 \mathrm{~h}$, then incubated at $4^{\circ} \mathrm{C}$ overnight with one of the following antibodies: anti-GluA2 (mouse, Millipore MAB397, 1:500), anti-GluA4 (rabbit, Millipore AB1508, 1:200), anti-cofilin (rabbit, Abcam ab42824, $1: 10,000)$. Transferred proteins were detected with appropriate horseradish peroxide-conjugated (HRP) secondary antibodies: goat anti-mouse IgG-HRP (Santa Cruz sc2005, 1:2000) or goat anti-rabbit IgG-HRP (Santa Cruz sc-2030, 1:2000), reacted with chemiluminescent ECL substrate (Thermo Scientific Pierce), and visualized by ChemiDoc MP System (Bio-Rad Laboratories). Band intensities of GluA2 and GluA4 were normalized to the respective cofilin bands or to the total protein determined 
by Ponceau S staining of the membranes (Image Lab 5.2, Bio-Rad Laboratories).

\section{Dissociated cerebellar cultures}

Cultures of dissociated cerebellar neurons were prepared from postnatal day (P)5-P7 mice. Briefly, after decapitation, the cerebella were removed, cut into small pieces and trypsinized at $37^{\circ} \mathrm{C}$. Mechanically dissociated cells were plated on poly-L-lysine-coated (Sigma) glass coverslips, at a density of $2.1 \times 10^{5}$ cells per coverslip. Cells were maintained in a humidified atmosphere at $37^{\circ} \mathrm{C}$ $\left(5 \% \mathrm{CO}_{2}\right)$ in basal medium Eagle (BME) supplemented with $10 \%$ fetal bovine serum (FCS; v/v), 2 mM L-glutamine, and $100 \mathrm{mg} \mathrm{ml}^{-1}$ gentamicin (all Gibco). Cells were maintained in "high $\mathrm{K}^{+}$" $(25 \mathrm{mM} \mathrm{KCl})$ to promote synaptic maturation. Cytosine arabinoside (10 $\mu \mathrm{M}$; Sigma) was added $24 \mathrm{~h}$ after plating to inhibit glial proliferation. In most cases, wild-type and $C / n 3^{\Delta e x 1-6}$ cultures were prepared concurrently and examined in interleaved recordings after 7-13 d.

\section{Electrophysiology of cultured granule cells}

Cells, identified according to previously described criteria (Cull-Candy et al., 1988), were viewed using a fixed-stage microscope (Zeiss Axioskop FS1 or Olympus BX51WI) and perfused at a rate of $1.5-2 \mathrm{ml} \mathrm{min}^{-1}(2-\mathrm{ml}$ bath volume). The extracellular solution contained 145 $\mathrm{mM} \mathrm{NaCl}, 2.5 \mathrm{mM} \mathrm{KCl}, 1 \mathrm{mM} \mathrm{CaCl}_{2}, 1 \mathrm{mM} \mathrm{MgCl}_{2}, 10 \mathrm{mM}$ glucose, and $10 \mathrm{mM}$ HEPES (adjusted to $\mathrm{pH} 7.3$ with $\mathrm{NaOH}$ ). Pipettes for whole-cell recording were pulled from thick-walled borosilicate glass $(1.5 \mathrm{~mm}$ o.d., $0.86 \mathrm{~mm}$ i.d., Harvard Apparatus), coated with Sylgard resin (Dow Corning 184) and fire-polished to a final resistance of $\sim 5-8 \mathrm{M} \Omega$. Pipettes were filled with a solution containing $145 \mathrm{mM}$ $\mathrm{CsCl}, 2.5 \mathrm{mM} \mathrm{NaCl}, 1 \mathrm{mM}$ Cs-EGTA, $4 \mathrm{mM} \mathrm{MgATP}$, and 10 mM HEPES (adjusted to $\mathrm{pH} 7.3$ with $\mathrm{CsOH}$ ). Spermine tetrahydrochloride (500 $\mu \mathrm{M}$, Sigma) was added to this intracellular solution immediately before each recording session.

Currents were recorded at $22-26^{\circ} \mathrm{C}$ using an Axopatch 1D or Axopatch 200B amplifier and acquired using pClamp10 and a Digidata 1200 interface (Molecular Devices). Series resistance and input capacitance were read directly from the amplifier settings used to minimize the current responses to 5-mV hyperpolarizing voltage steps; values were $6.3 \pm 0.4 \mathrm{pF}$ for wild-type versus $5.9 \pm 0.5 \mathrm{pF}$ for $\mathrm{Cln}^{\mathrm{Aex1-6}}(n=34$ and $42 ; \mathrm{W}=861.5, p=0.12$ Wicoxon rank sum test) and $25.2 \pm 0.8$ versus $27.3 \pm 1.2$ $\mathrm{M} \Omega(\mathrm{W}=604.5, p=0.25$ Wilcoxon rank sum test). Whole-cell current-voltage (I- $V$ ) relationships were generated by ramping membrane potential from -90 to +60 $\mathrm{mV}$ in the presence of $20 \mu \mathrm{M}$ s-AMPA and $10 \mu \mathrm{M}$ cyclothiazide (Ascent Scientific) applied by gravity-fed bath perfusion. Ramps were delivered once currents had reached steady-state amplitude. Records were filtered at $2 \mathrm{kHz}$ and sampled at $5 \mathrm{kHz}$. The rectification index (RI) was calculated as the ratio of slope conductance in positive $(+20$ to $+40 \mathrm{mV})$ and negative $(-40$ to $-20 \mathrm{mV})$ limbs of the $I-V$.

\section{mEPSCs in cultured granule cells}

Miniature EPSCs (mEPSCs) were recorded at $-60 \mathrm{mV}$ after blocking voltage-gated sodium channels, NMDA-, $\mathrm{GABA}_{\mathrm{A}^{-}}$, and glycine receptors by adding $1 \mu \mathrm{M}$ tetrodotoxin (TTX), $20 \mu \mathrm{M}$ D-AP5, $20 \mu \mathrm{M}$ SR-95531, and $1 \mu \mathrm{M}$ strychnine (Ascent Scientific). Before mEPSC recording, the cells were briefly exposed (2-3 min) to $200 \mu \mathrm{M} \mathrm{LaCl}_{3}$ to increase mEPSC frequency (Chung et al., 2008). The signal was filtered at $2 \mathrm{kHz}$ and sampled at $20 \mathrm{kHz}$. Event detection was performed using amplitude threshold crossing (Igor Pro 5, Wavemetrics Inc; NeuroMatic 2.02, www.neuromatic.thinkrandom.com), with the threshold (typically $\sim 5 \mathrm{pA}$ ) set to $3 \times$ the baseline current variance. The rectification index $\left(\mathrm{RI}_{\mathrm{CM}}\right)$ was calculated by dividing the mean mEPSC peak conductance calculated using all events detected at $+60 \mathrm{mV}$ and a matching number of the largest events at $-60 \mathrm{mV}$. For fluctuation analysis (see paragraph below) and kinetic analysis, only events that exhibited a monotonic rise and an uncontaminated decay were included. Such events were aligned on their rising phase before averaging. The decay of the averaged mEPSC was fitted with a double exponential, and the weighted time constant of decay $\left(\tau_{\mathrm{w} \text {, decay }}\right)$ calculated as the sum of the fast and slow time constants weighted by their fractional amplitudes. In some cases, mEPSCs were adequately fit with single exponentials.

Peak-scaled non-stationary fluctuation analysis (psNSFA) was used to estimate the weighted mean singlechannel conductance of synaptic receptors (Traynelis et al., 1993; Hartveit and Veruki, 2007). Each mEPSC was divided into 30 bins of equal amplitude, and, within each bin, the variance of the mEPSC about the scaled average was computed. The variance was plotted against the mean current value, and the weighted mean singlechannel current was estimated by fitting the full parabolic relationship with the equation:

$$
\sigma_{\mathrm{PS}}^{2}=i \bar{l}-\bar{l}^{2} / N_{\mathrm{p}}+\sigma_{\mathrm{B}}^{2}
$$

where $\sigma_{\mathrm{PS}}^{2}$ is the peak-scaled variance, $\bar{l}$ is the mean current, $i$ is the weighted mean single-channel current, $N_{\mathrm{p}}$ is the number of channels open at the peak of the EPSC, and $\sigma_{\mathrm{B}}^{2}$ is the background variance. The weighted mean chord conductance for each cell was calculated assuming a reversal of $0 \mathrm{mV}$.

\section{Acute cerebellar slices}

Mice (P10-P15) were anesthetized with isoflurane and decapitated. After brain dissection, $250-\mu \mathrm{m}$-thick sagittal slices were cut in an ice-cold oxygenated solution $(85 \mathrm{mM}$ $\mathrm{NaCl}, 2.5 \mathrm{mM} \mathrm{KCl}, 0.5 \mathrm{mM} \mathrm{CaCl}_{2}, 4 \mathrm{mM} \mathrm{MgCl}, 25 \mathrm{mM}$ $\mathrm{NaHCO}_{3}, 1.25 \mathrm{mM} \mathrm{NaH} \mathrm{PO}_{4}, 64 \mathrm{mM}$ sucrose, and 25 $\mathrm{mM}$ glucose; $\mathrm{pH} 7.3$ when bubbled with $95 \% \mathrm{O}_{2}$ and $5 \%$ $\mathrm{CO}_{2}$ ), using a vibratome (Microm HM $650 \mathrm{~V}$ or Campden 7000 smz). To prevent NMDAR-mediated cell damage 20 $\mu \mathrm{M}$ D-AP5 (Tocris Bioscience) was included. Slices were stored in the same solution at $35^{\circ} \mathrm{C}$ for $30 \mathrm{~min}$ and then transferred into recording "external" solution at $23-26^{\circ} \mathrm{C}$ (125 mM NaCl, $2.5 \mathrm{mM} \mathrm{KCl}, 2 \mathrm{mM} \mathrm{CaCl}_{2}, 1 \mathrm{mM} \mathrm{MgCl}_{2}, 25$ $\mathrm{mM} \mathrm{NaHCO} 3,1.25 \mathrm{mM} \mathrm{NaH}_{2} \mathrm{PO}_{4}$, and $25 \mathrm{mM}$ glucose; $\mathrm{pH} 7.3$ when bubbled with $95 \% \mathrm{O}_{2} / 5 \% \mathrm{CO}_{2}$ ). 


\section{Slice electrophysiology}

Slices were viewed using a fixed stage upright microscope (Olympus BX 51WI with infrared differential interference contrast or oblique illumination) and recordings were made from visually identified neurons in the internal granule cell layer (Kaneda et al., 1995). To block NMDA and GABA $_{A}$ receptors, $20 \mu \mathrm{M}$ D-APV and $20 \mu \mathrm{M}$ SR95531 (Ascent Scientific) were added. The internal solution contained $128 \mathrm{mM} \mathrm{CsCl}, 10 \mathrm{mM}$ HEPES, $10 \mathrm{mM}$ EGTA, $2 \mathrm{mM} \mathrm{Mg}{ }_{2}$ ATP, $0.5 \mathrm{mM} \mathrm{CaCl}_{2}, 2 \mathrm{mM} \mathrm{NaCl}, 5 \mathrm{mM}$ TEA, $1 \mathrm{mM} \mathrm{N}$-(2,6-dimethylphenylcarbamoylmethyl) triethylammonium bromide (QX-314), and $0.1 \mathrm{mM}$ spermine tetrahydrochloride $(\mathrm{pH} 7.3$ with $\mathrm{CsOH})$. Currents were recorded using an Axopatch 200B amplifier, filtered at 2 $\mathrm{kHz}$ and digitized at $20 \mathrm{kHz}$ (pClamp 10.2 Molecular Devices or Igor Pro 5 with NeuroMatic). All currents were recorded at room temperature, with the exception of minimally evoked EPSCs (meEPSCs; see 'Quanta and evoked EPSCs' below). Series resistance and input capacitance were read directly from the amplifier settings used to minimize the current responses to $5-\mathrm{mV}$ hyperpolarizing voltage steps. Series resistance was compensated (up to $75 \%$ ). Measured values at room temperature were $3.9 \pm$ $0.3 \mathrm{pF}$ for wild type versus $3.6 \pm 0.3 \mathrm{pF}$ for $\mathrm{C} / n 3^{\Delta e \times 1-6}(n=$ 11 and $12 ; \mathrm{W}=76.5, p=0.54$ Wilcoxon rank sum test) and $10.0 \pm 0.5$ versus $12.4 \pm 1.0 \mathrm{M} \Omega(\mathrm{W}=40.5, p=0.12$ Wilcoxon rank sum test).

\section{Quantal and evoked EPSCs}

To record quantal EPSCs (qEPSCs), the standard extracellular solution was replaced with $\mathrm{a} \mathrm{Ca}^{2+}$-free solution containing $5 \mathrm{mM} \mathrm{SrCl}_{2}$ (Goda and Stevens, 1994; AbdulGhani et al., 1996). Mossy fibers were stimulated $(0.5 \mathrm{~Hz})$ using a concentric bipolar tungsten electrode placed in the white matter tract (Digitimer DS/2A constant voltage stimulator; $100 \mathrm{~V} / 200 \mu \mathrm{s})$. Events were detected using amplitude threshold crossing, with the threshold (typically $\sim 5 \mathrm{pA}$ ) set according to the baseline current variance. To avoid the inclusion of multiquantal events, only qEPSCs occurring $>10 \mathrm{~ms}$ after the mossy fiber stimulus were included. When analyzing event frequency, any qEPSC with a distinct peak was included. When analyzing qEPSC amplitude, all events with a monotonic rise were included, irrespective of overlapping decays. For kinetic analysis, only events with a monotonic rise and uncontaminated decay were included; they were aligned on their rising phase before averaging. The decay of the averaged qEPSC was fitted with a double exponential, and the weighted time constant of decay $\left(\tau_{\mathrm{w}, \text { decay }}\right)$ calculated.

To record eEPSCs, mossy fibers were stimulated $(0.5$ $\mathrm{Hz}$ ) using a concentric bipolar tungsten electrode placed in the white matter tract (Digitimer DS/2A constant voltage stimulator). Pairs of eEPSCs were recorded at room temperature with an extracellular solution containing $2 \mathrm{mM}$ $\mathrm{Ca}^{2+} / 1 \mathrm{mM} \mathrm{Mg}^{2+}$.

To more closely approximate physiologically relevant conditions, meEPSCs were recorded at an elevated temperature $\left(30-34^{\circ} \mathrm{C}\right)$. Mossy fibers were stimulated using constant voltage pulses (80-100 $\mu \mathrm{s} ; 20-48 \mathrm{~V})$ delivered through a glass electrode filled with extracellular solution positioned $\sim 100-200 \mu \mathrm{m}$ from the recorded granule cell. The criteria for minimal stimulation included an initial $\sim 30 \%$ failure rate during repeated single stimuli at 0.25 $\mathrm{Hz}$ and invariant EPSC latency and amplitude with increased stimulus intensity. The mean voltage of the threshold stimulus was $32.7 \mathrm{~V}$ for wild-type cells and $34.2 \mathrm{~V}$ for $\mathrm{C} / n 3^{\Delta e x 1-6}$ cells. For each cell, trains of five stimuli $(100 \mathrm{~Hz}, \sim 2 \mathrm{~V}$ above threshold) were delivered at 3-s intervals and meEPSCs recorded at $-70 \mathrm{mV}$ in both "high" and "low" extracellular $\mathrm{Ca}^{2+}\left(2 \mathrm{mM} \mathrm{Ca}^{2+} / 1 \mathrm{mM} \mathrm{Mg}^{2+}\right.$ and $1 \mathrm{mM} \mathrm{Ca}^{2+} / 2 \mathrm{mM}$ $\left.\mathrm{Mg}^{2+}\right)$. In each case the amplitudes of evoked currents were normalized to the mean amplitude of the first response $\left(\right.$ meEPSC $_{1}$ ) in $2 \mathrm{mM} \mathrm{Ca}^{2+} / 1 \mathrm{mM} \mathrm{Mg}^{2+}$

\section{Transmission electron microscopy}

Sagittal slices $(200 \mu \mathrm{m})$ of cerebellar vermis were prepared from six P13 C57BL/6 mice and three age-matched $\mathrm{Cln} 3^{\Delta e \times 1-6}$ mice, as described above. Slices were cut in slicing solution, immediately transferred into $4 \%$ paraformaldehyde and $0.5 \%$ glutaraldehyde, and left overnight at $4^{\circ} \mathrm{C}$. Following primary fixation, the tissue was washed and osmicated for $1 \mathrm{~h}$ at $4^{\circ} \mathrm{C}$ in $1 \% \mathrm{OsO}_{4}$ in $0.1 \mathrm{M}$ phosphate buffer, enblocked, stained in $2.0 \%$ uranyl acetate buffer for $30 \mathrm{~min}$ at $4^{\circ} \mathrm{C}$, dehydrated in ethanols, cleared in propylene oxide, and embedded in Araldite. Sections of 70-80 nm in thickness were made. These were collected on copper mesh grids, counterstained with lead citrate, and viewed in a JEOL 1010 electron microscope.

Mossy fiber axons were identified by their structural characteristics (Xu-Friedman and Regehr, 2003). Release sites were identified by the presence of a presynaptic cluster of vesicles close to the membrane, active zone material and a postsynaptic density. Electron micrographs were analyzed by individuals blinded to the genotype and quantified using ImageJ software (v1.46; https://imagej.nih.gov/ij/). To evaluate the density of vesicles in each terminal, a grid composed of multiple squares (each with an area $0.1 \mu \mathrm{m}^{2}$ ) was overlaid on the image. We counted the number of vesicles (of $\sim 30 \mathrm{~nm}$ in diameter) within each square. Squares containing organelles, or those containing the border of the mossy fiber terminal were excluded from analysis. Vesicles were considered to be proximal to the release site if they were $<100 \mathrm{~nm}$ from the presynaptic membrane of an active zone. The active zone vesicle density was then calculated as the number of vesicles per $50 \mathrm{~nm}$ of active zone length. As accurate identification of docked vesicles is demanding, even in much thinner slices than used here (Molnár et al., 2016), we opted to count those within one vesicle radius of the active zone and term them "membrane adjacent" vesicles.

\section{Statistical analysis}

Summary data are presented in the text as mean \pm SEM from $n$ cells (or mossy fiber terminals). Comparisons involving two datasets only were performed using a Wilcoxon rank sum test. For the comparison of paired-pulse ratios (PPRs) at different frequencies and analysis of short-term plasticity, we used two- and three-way repeated measures ANOVA. For EM data, nested analysis was performed using a likelihood ratio test comparing two 
linear mixed-effect models (Bates et al., 2015). Exact $p$ values are presented to two significant figures, except when $p<0.0001$. Differences were considered significant at $p<0.05$. Statistical tests were performed using $R$ (version 3.3.2; the R Foundation for Statistical Computing; http://www.r-project.org/) and R Studio (version 1.1.383; RStudio). No statistical test was used to predetermine sample sizes; these were based on standards of the field.

\section{Results}

\section{Levels of GluA2 and GluA4 are unaltered in cerebella of $C \ln 3^{\Delta e x 1-6}$ mice}

The increased AMPAR-mediated excitotoxicity seen in dissociated and slice cultures of cerebellum from 8- to $10-\mathrm{d}$-old $C / n 3^{\Delta e \times 1-6}$ mice was originally suggested to reflect altered AMPAR trafficking, and a possible increase in the number of GluA2-lacking CP-AMPARs (Kovács et al., 2006). However, the same authors later described an increase in GluA2 protein in the cerebellum of one-monthold $C / n 3^{\Delta e x 1-6}$ mice (Kovács et al., 2015). To investigate possible AMPAR subunit changes, we initially measured protein levels for GluA2 and GluA4 in cerebellum from wild-type and $\mathrm{Cln} 3^{\Delta e \times 1-6}$ mice in the second postnatal week, around the age when the first structural and functional defects are observed in $\mathrm{C} / n 3^{\Delta e \times 1-6}$ mice (Weimer et al., 2009).

We prepared cerebellar tissue lysate from 12 wild-type and $12 \mathrm{Cln} 3^{\operatorname{sex} 1-6}$ mice (P14-P16). For each group, four samples were generated by pooling tissue from three littermate mice. All eight samples were run together and the membrane probed with the relevant antibodies (mouse anti-GluA2, mouse anti-GluA4, rabbit anti-cofilin; see Materials and Methods; Fig. 1A,B). We found no difference in total protein for either GluA2 $(0.29 \pm 0.04$ for wild type vs $0.29 \pm 0.06$ for $C / n 3^{\Delta e x 1-6}$, normalized to the intensity of the cofilin band; $\mathrm{W}=10, p=0.69)$ or GluA4 $(0.33 \pm 0.05$ vs $0.30 \pm 0.07$ normalized to the intensity of cofilin; $W=$ $9, p=0.89$; Fig. $1 C, D$ ). Similar results were obtained when values were normalized to total protein (data not shown; see Materials and Methods).

\section{AMPA-evoked currents are unchanged in cultured Cln $3^{\Delta e \times 1-6}$ granule cells}

To determine whether the magnitude of AMPAR-mediated currents or the prevalence of CP-AMPARs was altered in cerebellar granule cells from $\mathrm{Cln} 3^{\Delta e \times 1-6}$ mice, we first made recordings from cultured neurons and examined whole-cell currents evoked by bath application of AMPA $(20 \mu \mathrm{M})$. The responses were compared during voltage ramps from -90 to $+60 \mathrm{mV}$, with spermine $(500 \mu \mathrm{M})$ included in the pipette (intracellular) solution (Fig. 2A). As this polyamine blocks CP-AMPARs in a voltage-dependent manner, with pronounced block at depolarized potentials, it allows their presence to be identified from the characteristic inwardly rectifying $I-V$ relationship (Bowie and Mayer, 1995; Kamboj et al., 1995; Koh et al., 1995).

We found the mean current amplitude at $-90 \mathrm{mV}$ was unaltered in $\mathrm{Cln}^{\mathrm{\Delta ex}{ }^{-6}-6}$ cells compared with wild-type (wild-type $131.9 \pm 41.4$ and $C \ln 3^{\operatorname{\Delta ex1-6}} 126.4 \pm 34.7, n=$ 10 and 13 , respectively; $W=67, p=0.95$; Fig. $2 A, B$ ). This
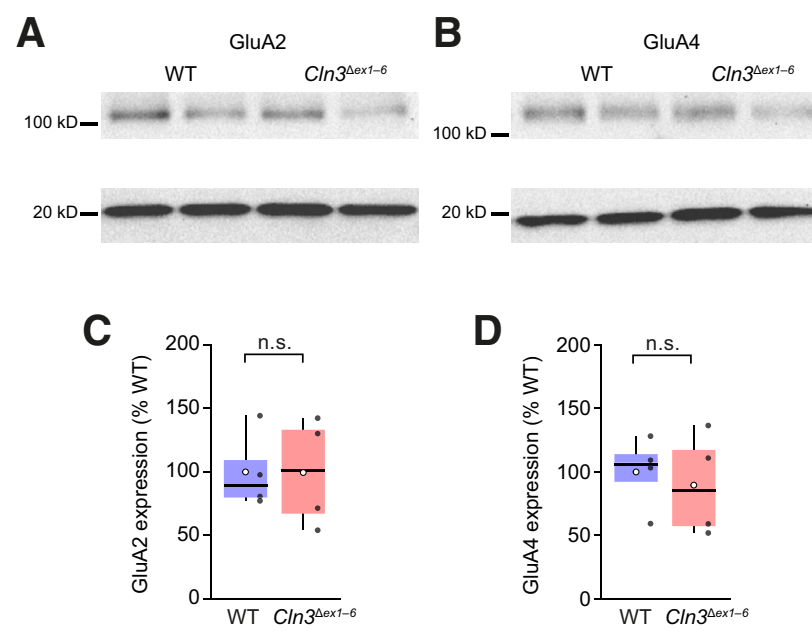

Figure 1. GluA2 and GluA4 expression is unaltered in cerebellum of $C / n 3^{\Delta e x 1-6}$ mice. $\boldsymbol{A}$, Representative western blots comparing the expression of GluA2 in cerebellar lysates from wild-type (WT) and $C / n 3^{\Delta e x 1-6}$ mice. Each lane uses pooled tissue from three littermate mice. Upper bands (near $100 \mathrm{kDa}$ ) show the labeling for GluA2. Lower bands (at $20 \mathrm{kDa}$ ) show the corresponding labeling for cofilin. B, Same as $\boldsymbol{A}$ but for GluA4. C, Pooled data for GluA2 expression normalized to mean WT expression. Boxand-whisker plots indicate the median value (black line), the 25-75th percentiles (box), and the 10-90th percentiles (whiskers); filled black circles are data from individual cells and open circles indicate means. $\boldsymbol{D}$, Same as $\boldsymbol{C}$ but for GluA4 (n.s., nonsignificant; Wilcoxon rank sum test).

situation persisted when current amplitudes were normalized to the measured cell capacitance. Moreover, the $I-V$ plots were similar. Cells from both wild-type and $C \ln 3^{\Delta e x 1-6}$ mice exhibited near-linear I-V relationships (Fig. 2C-E), with rectification indices (RIs; see Materials and Methods) of $0.91 \pm 0.08$ and $0.85 \pm 0.07, n=9$ and 10 , respectively $(\mathrm{W}=52, p=0.60)$. This observation suggests that loss of CLN3 does not alter the predominant expression of $\mathrm{Cl}$ AMPARs in cultured granule cells.

\section{mEPSCs and synaptic AMPARs are unaltered in granule cells from $\mathrm{Cln} 3^{\Delta e \times 1-6}$ mice}

We next examined synaptic AMPARs by recording mEPSCs in the presence of TTX $(1 \mu \mathrm{M}$; Fig. $3 A-D)$. The amplitude and frequency of mEPSCs at $-60 \mathrm{mV}$ was similar in cells cultured from wild-type and $\mathrm{Cln}^{\mathrm{Dex} 1-6}$ mice $(10.7 \pm 0.8$ vs $9.8 \pm 0.5 \mathrm{pA}, \mathrm{W}=374, p=0.49$ and $3.1 \pm 1.1$ vs $2.5 \pm 0.9 \mathrm{~Hz}, \mathrm{~W}=404, p=0.22 ; n=24$ and 28 cells, respectively; Fig. $3 C-E$ ).

To determine whether loss of CLN3 led to an alteration in the basic properties of synaptic AMPARs in granule cells, we assessed their kinetics, voltage-dependence and mean single-channel conductance by analyzing synaptic currents. The 10-90\% risetime and weighted decay of mEPSCs (see Materials and Methods) did not differ between cells cultured from wild-type and $C / n 3^{\operatorname{sex} 1-6}$ mice $(0.33 \pm 0.02$ vs $0.34 \pm 0.02 \mathrm{~ms}, \mathrm{~W}=36, p=0.76$ and $1.27 \pm 0.10$ vs $1.42 \pm 0.12 \mathrm{~ms}, \mathrm{~W}=33, p=0.57$; $n=10$ and 8 cells). Likewise, we found no difference in the weighted mean single-channel conductance determined using ps-NSFA (see Materials and Methods; 
A

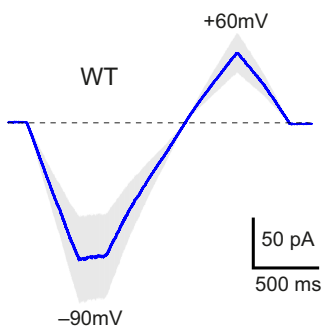

C

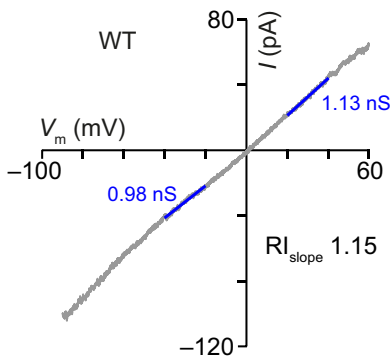

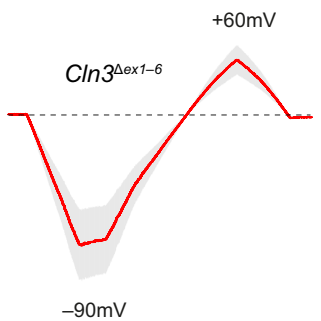

D

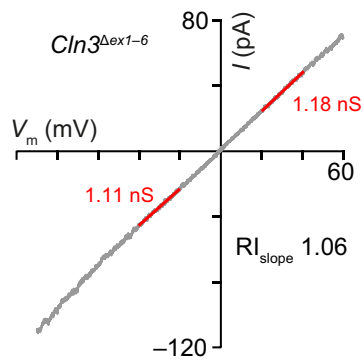

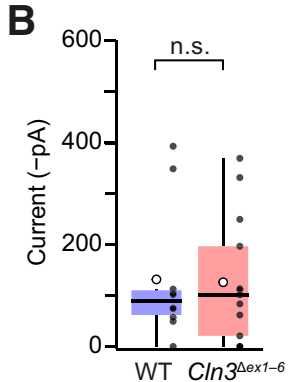

E

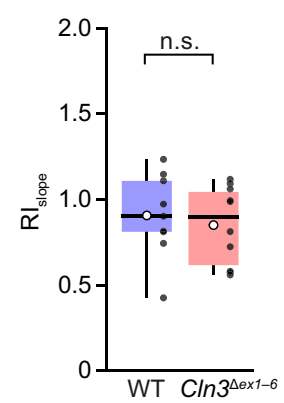

Figure 2. AMPA-evoked whole-cell currents from granule cells of $C / n 3^{\Delta e x 1-6}$ mice are similar. $\boldsymbol{A}$, Global average waveforms of leak-subtracted AMPA-evoked currents (in the presence of $10 \mu \mathrm{M}$ cyclothiazide) from wild-type (WT) and Cln3 $3^{\Delta e x 1-6}$ mice (10 and 13 cells, respectively). Shaded areas denote SEM. $\boldsymbol{B}$, Pooled data showing no change in amplitude $(-90 \mathrm{mV})$ in cells from Cln $3^{\Delta e x 1-6}$ mice. $\boldsymbol{C}$, Representative I-V relationship from a WT cell. Fitted blue lines (from -40 to $-20 \mathrm{mV}$ and from +20 to $+40 \mathrm{mV}$ ) indicate the slope conductances $\left(G_{\text {slope }}\right)$ for the negative and positive limbs of the $I-V$ relationship. The rectification index (indicated) was calculated as $R \mathrm{I}_{\text {slope }}=G_{\text {slope }}$ pos $/ G_{\text {slope }}$ neg. $\boldsymbol{D}$, Same as $\boldsymbol{C}$ but for a representative granule cell from a $C / n 3^{\Delta e x 1-6}$ mouse. $\boldsymbol{E}$, Pooled data showing similar rectification in cells from WT and $C / n 3^{\Delta e x 1-6}$ mice. Box-and-whisker plots as in Figure 1 (n.s., non-significant; Wilcoxon rank sum test).

$11.5 \pm 1.5$ vs $11.2 \pm 0.9 \mathrm{pS}, \mathrm{W}=40, p=1.00 ; n=10$ and 8 cells; Fig. $3 F)$ or in mEPSC rectification $\left(\mathrm{RI}_{\mathrm{CM}}+60 /-60\right.$ $\mathrm{mV}$; see Materials and Methods; $0.99 \pm 0.05$ vs $1.05 \pm$ $0.08, \mathrm{~W}=36, p=0.65 ; n=12$ and 7 cells; Fig. $3 G$ ). The fact that the mEPSCs remained non-rectifying and their underlying single-channel conductance remained low in $C / n 3^{\Delta e \times 1-6}$ mice suggests that, in keeping with the data from whole-cell AMPA-evoked currents, Cl-AMPARs are the predominant subtype present at granule cell synapses following loss of CLN3.

\section{Quantal events at mossy fiber-granule cell synapses of $C \ln 3^{\Delta e \times 1-6}$ mice}

To investigate transmission at mossy fiber to granule cell synapses formed in vivo, we next moved to acute cerebellar slices. As spontaneous mEPSCs occurred only at low frequency, we initially examined quantal events (qEPSCs) in response to mossy fiber stimulation. We made recordings in the presence of $5 \mathrm{mM}$ extracellular $\mathrm{SrCl}_{2}$ to trigger the asynchronous release of transmitter such that individual quanta could be identified (Fig. $4 A, B$ ). This approach allowed us to measure both the size and the number of quanta released per stimulus.

Unexpectedly, in slices from $C / n 3^{\operatorname{sex1-6}}$ mice, each mossy fiber stimulation evoked a smaller initial EPSC and far fewer discrete qEPSCs than in wild type (initial amplitude reduced from $-52.3 \pm 6.9 \mathrm{pA}$ to $-21.2 \pm 6.3 \mathrm{pA}, n=$ 6 and $7, W=4, p=0.014$ and number of quantal events reduced from $10.0 \pm 2.6-2.5 \pm 0.7 ; \mathrm{W}=41, p=0.0023$;
Fig. 4C). Of note, in slices from wild-type mice no "failures" (sweeps in which no response was evoked) were seen, but in slices from $\mathrm{Cln} 3^{\operatorname{\Delta ex} 1-6}$ mice, the average failure rate was $\sim 10 \%$ (range $0-23.3 \%$ ). In slices from $\mathrm{C} / \mathrm{n}^{\mathrm{\Delta ex1-6}}$ mice the amplitude of qEPSCs was similar to wild-type (14.0 \pm 1.6 vs $12.4 \pm 1.5 \mathrm{pA}, n=6$ and $7 ; \mathrm{W}=$ $24, p=0.73$; Fig. $4 D$ ), and both the $10-90 \%$ risetime $\left(\mathrm{RT}_{10-90 \%} ; 0.34 \pm 0.01\right.$ vs $0.33 \pm 0.03 \mathrm{~ms} ; \mathrm{W}=30.5, p=$ $0.20)$ and weighted decay time $\left(\tau_{\mathrm{w} \text {, decay }} ; 2.11 \pm 0.23\right.$ vs $2.79 \pm 0.44 \mathrm{~ms} ; \mathrm{W}=13, p=0.29$ ) of qEPSCs remained unchanged (Fig. 4E). These results demonstrate no change in postsynaptic responsiveness at mossy fiber synapses of $C / n 3^{\Delta e x 1-6}$ mice, but the activation of fewer mossy fibers or a potential reduction in the probability of transmitter release.

\section{Unaltered paired-pulse depression of eEPSCs in Cln $3^{\Delta e x 1-6}$ granule cells}

Mossy fiber-granule cell synapses are known to sustain high bandwidth transmission, but the majority show an initial short-term depression during high frequency stimulation (Nieus et al., 2006; Saviane and Silver, 2006; Chabrol et al., 2015). Although the reduced number of qEPSCs in slices from Cln $3^{\Delta e x 1-6}$ mice could be consistent with a decrease in release probability in $0 \mathrm{Ca}^{2+} / 5$ $\mathrm{mM} \mathrm{Sr}{ }^{2+}$, this was not evident when we examined eEPSCs in $2 \mathrm{mM} \mathrm{Ca}^{2+}$. Responses to paired stimuli at 5, 10, 20 and $100 \mathrm{~Hz}$ showed no difference in PPR. For example, at $100 \mathrm{~Hz}$, the PPR indicated similar magnitude of depres- 
A

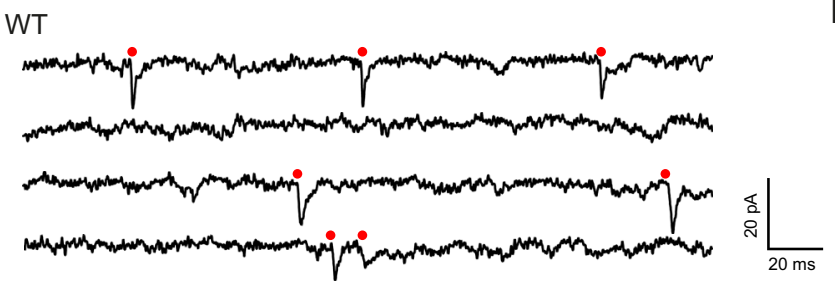

C WT
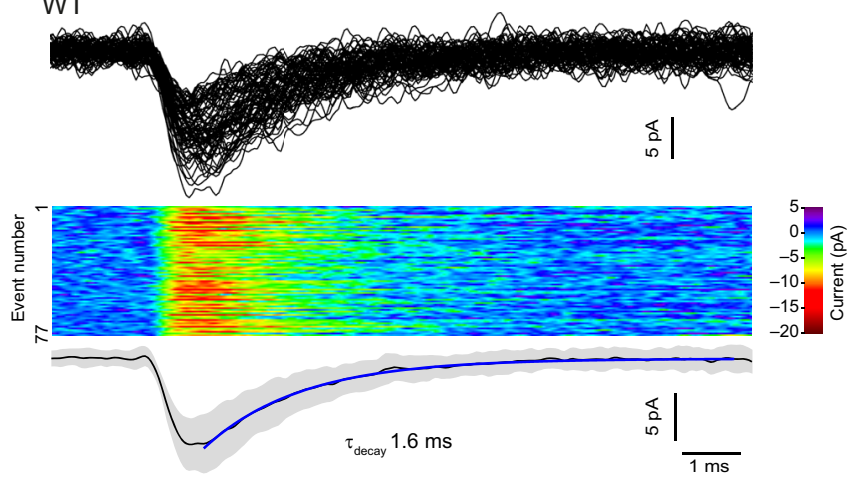

E
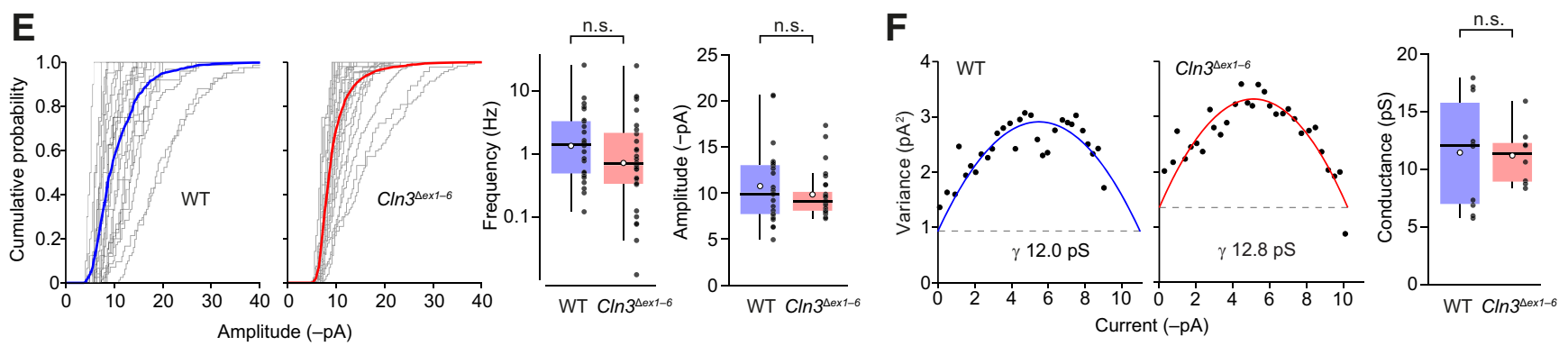

G

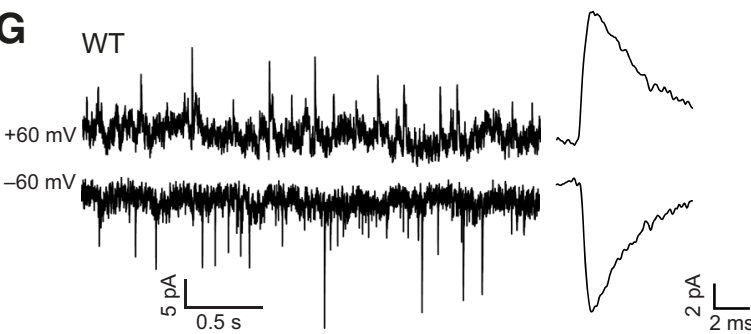

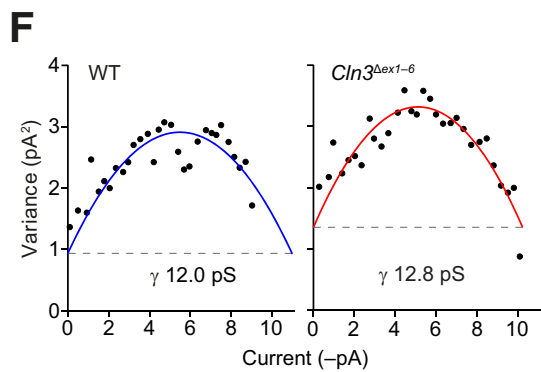

B

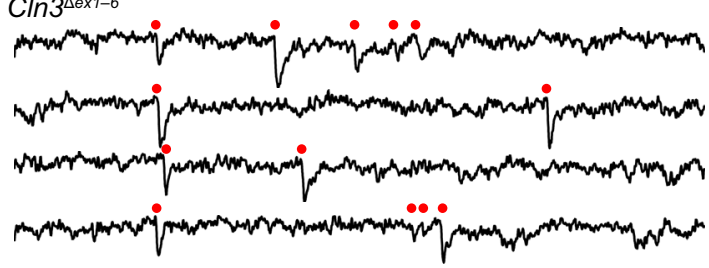

D $\ln 3^{\operatorname{sex} 1-6}$
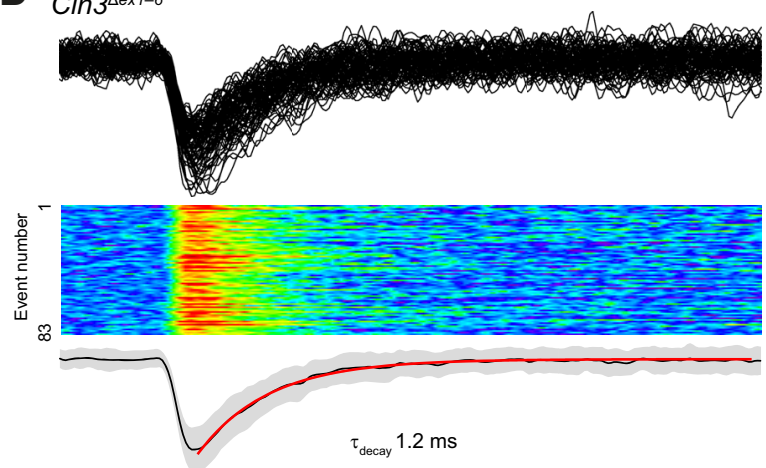

$\mathbf{F}$

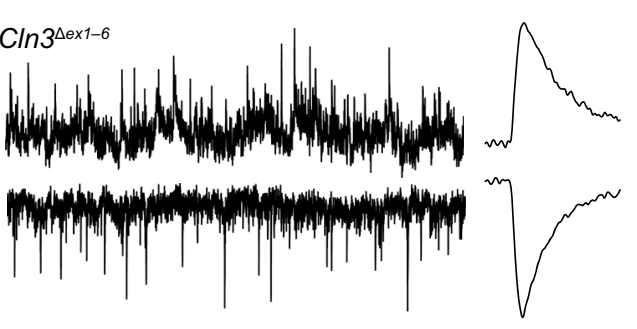

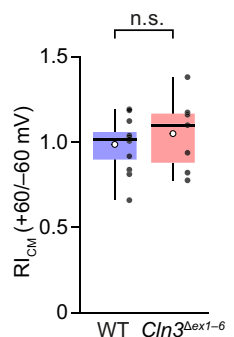

Figure 3. mEPSCs in granule cells from wild-type (WT) and $C \ln 3^{\Delta e \times 1-6}$ mice are indistinguishable. $\boldsymbol{A}$, Representative recording of mEPSCs from a granule cell in a culture prepared from WT mice $(-60 \mathrm{mV})$. Traces are consecutive and filtered at $1 \mathrm{kHz}$ for display (mEPSCs are indicated by red dots). $\boldsymbol{B}$, Same as $\boldsymbol{A}$ but from a granule cell in a culture prepared from $\mathrm{C} / n 3^{\Delta e x 1-6}$ mice. Scale bars apply to both $\boldsymbol{A}, \boldsymbol{B}$. C, upper, Individual mEPSCs from the cell in a, aligned at their point of steepest rise. Middle, Color-coded image of all 77 events. Lower, Averaged mEPSC (black trace) with superimposed SEM (gray fill) and exponential fit to the decay (blue line). The time constant $\left(\tau_{\text {decay }}\right)$ is indicated. $\boldsymbol{D}$, Same as $\boldsymbol{C}$ but for mEPSCs from the $C / n 3^{\Delta e x 1-6}$ recording in $\boldsymbol{B}$ (scale bars apply to both $\boldsymbol{C}, \boldsymbol{D}$ ). $E$, Pooled data showing similar amplitude and frequency of mEPSCs in granule cells from WT and $C / n 3^{\Delta e x 1-6}$ mice. Left, Cumulative probability distributions for mEPSC amplitudes. The averaged distributions are shown in bold (WT blue; Cln $3^{\Delta e x 1-6}$ red). Right, Box-and-whisker plots (as in Fig. 1) for mEPSC frequency ( $\log _{10}$ scale) and amplitude (n.s., non-significant; Wilcoxon rank sum test). $\boldsymbol{F}$, left, Representative current-variance relationships. The dashed line indicates the background current variance. The single-channel conductance $(\gamma)$ was calculated from the weighted-mean unitary current estimated from the parabolic fit. Right, Box-and-whisker plots (as in $\boldsymbol{E}$ ) showing similar values for conductance. $\boldsymbol{G}$, Representative recordings from cultured granule cells at -60 and $+60 \mathrm{mV}$ with corresponding count-matched averaged mEPSCs (see Materials and Methods). Traces are from a WT cell (left) and a C/n $3^{\Delta e \times 1-6}$ cell (right). Far right, Box-and-whisker plots (as in $\boldsymbol{E}$ ) showing pooled data for count-matched rectification index $\left(\mathrm{RI}_{\mathrm{CM}}\right)$.

sion $(0.41 \pm 0.13$ and $0.30 \pm 0.05$ for wild-type and Cln $3^{\Delta e \times 1-6}$ cells; $n=5$ and 4 , respectively; $\mathrm{W}=10, p=$ 1.00 , Wilcoxon rank sum test). Across the frequency range examined, two-way RM ANOVA showed an effect of inter stimulus interval $\left(F_{(3,21)}=16.88, p<0.0001\right)$, no effect of genotype $\left(F_{(1,7)}=0.24, p=0.64\right)$, and no interaction $\left(F_{(3,21)}=0.80, p=0.51\right)$. As both qEPSCs and eEPSCs were recorded under "non-physiological" conditions, we next chose to examine synaptic transmission at near-physiological temperature, and in $1 \mathrm{mM}$ extracellular 


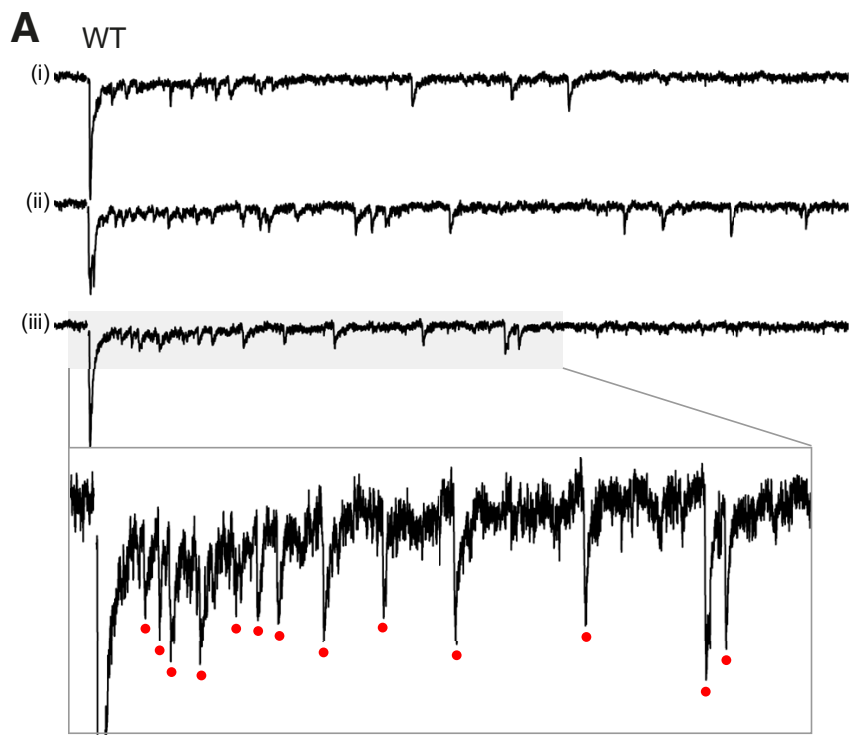

B $C \ln 3^{\operatorname{sex} 1-6}$
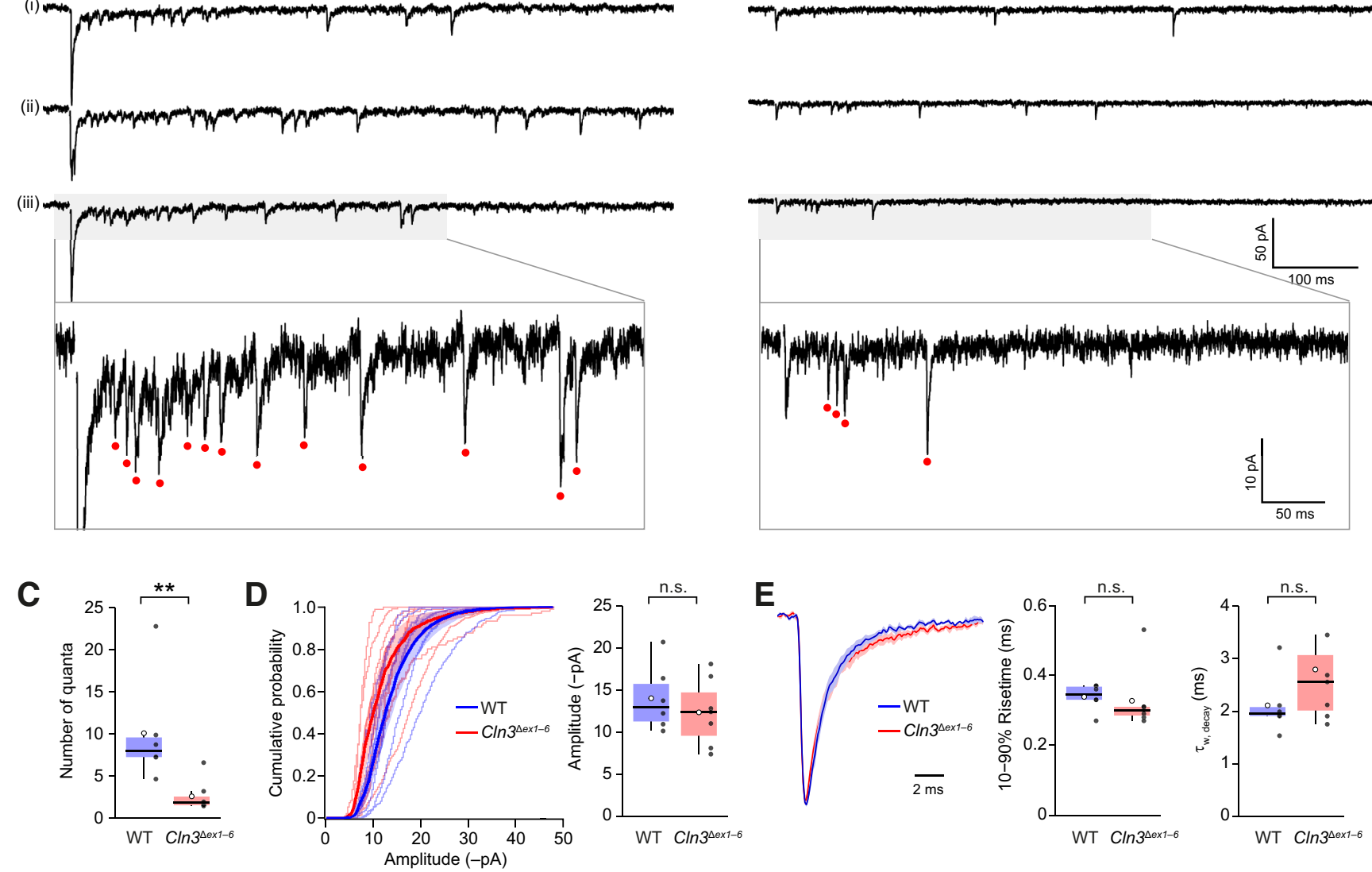

Figure 4. Reduced number of mossy fiber-evoked quantal events in granule cells in acute cerebellar slices from $C / n 3^{\Delta e x 1-6}$ mice. $\boldsymbol{A}$, Representative mossy fiber-evoked responses recorded from a wild-type (WT) granule cell $\left(-70 \mathrm{mV} ; 0 \mathrm{Ca}^{2+} / 5 \mathrm{mM} \mathrm{Sr}^{2+}\right)$. Three consecutive records are shown (i-iii). The region indicated in gray is enlarged in the lower panel to show the detected qEPSCs (red dots). $\boldsymbol{B}$, Same as $\boldsymbol{A}$ but in a cell from a $C / n 3^{\Delta e x 1-6}$ mouse (scale bars apply to both $\boldsymbol{A}, \boldsymbol{B}$ ). $\boldsymbol{C}$, Box-and-whisker plots (as in Fig. 1) showing the reduced number of discrete quanta evoked in cells from Cln $3^{\Delta e x 1-6}$ mice (**p $<0.01$; Wilcoxon rank sum test). $\boldsymbol{D}$, Cumulative probability distributions for qEPSC amplitudes. Data from each cell are shown together with the averaged distributions in bold (WT, blue; $C / n 3^{\operatorname{Lex} 1-6}$, red). Shaded areas denote SEM. Right, Box-and-whisker plots (as in C) showing unaltered qEPSC amplitude in cells from $C / n 3^{\Delta e x 1-6}$ mice. $E$, Superimposed normalized global average qEPSC waveforms from six WT and seven CIn $3^{\Delta e x 1-6}$ cells show no differences. Shaded areas denote SEM. Right, Box-and-whisker plots (as in C) for qEPSC 10-90\% risetime and $\tau_{\mathrm{w} \text {, decay }}$ (n.s., non-significant; Wilcoxon rank sum test).

$\mathrm{Ca}^{2+}$, a concentration thought likely to approximate more closely the situation in vivo (Borst, 2010).

\section{Altered short-term plasticity of meEPSCs in $C \ln 3^{\Delta e x 1-6}$ mice in reduced $\left[\mathrm{Ca}^{2+}\right]_{\text {。 }}$}

We examined meEPSCs in response to brief trains of high frequency mossy fiber stimulation (five stimuli at 100 $\mathrm{Hz}$ ) at $30-34^{\circ} \mathrm{C}$ in both "normal" and reduced extracellular $\mathrm{Ca}^{2+}\left(2 \mathrm{mM} \mathrm{Ca}^{2+} / 1 \mathrm{mM} \mathrm{Mg}^{2+}\right.$ and $1 \mathrm{mM} \mathrm{Ca}^{2+} / 2 \mathrm{mM}$ $\mathrm{Mg}^{2+}$; Fig. 5A,B). For each cell (six wild type and six $C / n 3^{\operatorname{sex} 1-6}$, meEPSC amplitudes were normalized to that of the first event in $2 \mathrm{mM}$ extracellular $\mathrm{Ca}^{2+}$. In both groups of mice, we observed a wide range of amplitudes for the first meEPSC (peak conductance of 0.56-2.91 nS for wild-type and $0.33-1.56 \mathrm{nS}$ for $\mathrm{Cln} 3^{\mathrm{Dex} 1-6}$ ), within the wide range (0.11-3.33 nS) reported by Chabrol et al. (2015) for different mossy fiber input pathways. In $2 \mathrm{mM}$ $\mathrm{Ca}^{2+}$, meEPSCs in granule cells from wild-type mice exhibited short-term depression $\left(\mathrm{meEPSC}_{2} / \mathrm{meEPSC}_{1}\right.$ was $0.46 \pm 0.07 ; \mathrm{W}=36, p=0.0028$ ). When the same cells were recorded in $1 \mathrm{mM}$ extracellular $\mathrm{Ca}^{2+}$, there was no depression $\left(\mathrm{meEPSC}_{2} / \mathrm{meEPSC}_{1}\right.$ was $0.81 \pm 0.12$; $\mathrm{W}=27, p=0.18$; Fig. $5 A$ ). However, for $\mathrm{Cln} 3^{\Delta e \times 1-6}$ cells, paired-pulse depression was seen in both 2 and $1 \mathrm{mM}$ extracellular $\mathrm{Ca}^{2+}(0.30 \pm 0.05$ and $0.31 \pm 0.06$, respectively; both $\mathrm{W}=36, p=0.0028$ and $p=0.0022$ ). A three-way repeated measures ANOVA was run to examine the effect of stimulus number, extracellular $\mathrm{Ca}^{2+}$ concentration and genotype on meEPSC amplitude (normalized to meEPSC ${ }_{1}$ in $2 \mathrm{mM} \mathrm{Ca}^{2+}$ ). There was a significant three-way interaction, $F_{(4,80)}=3.67, p=0.0085$. Thus, the effect of lowering extracellular $\mathrm{Ca}^{2+}$ on the meEPSC amplitudes during short trains was affected by deletion of CLN3. Overall, these results suggest altered release dynamics in $C / n 3^{\Delta e \times 1-6}$ mice, that are revealed in conditions of reduced extracellular $\mathrm{Ca}^{2+}$. Of note, the mean amplitude of meEPSC ${ }_{1}$ in $2 \mathrm{mM} \mathrm{Ca}^{2+}$ did not differ between genotypes $(77.3 \pm 26.0$ and $69.7 \pm 12.0$ pA; 
A

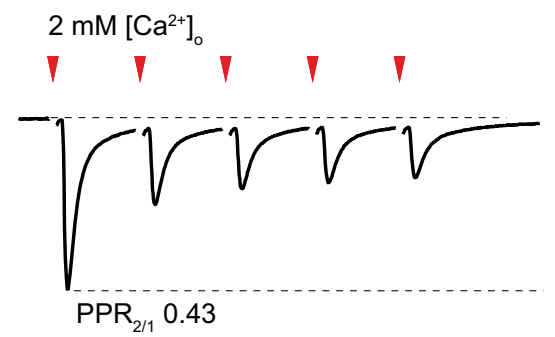

WT

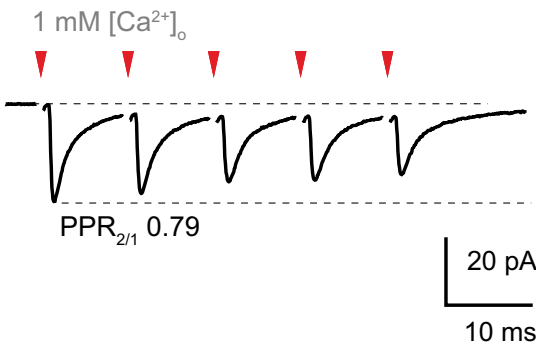

B

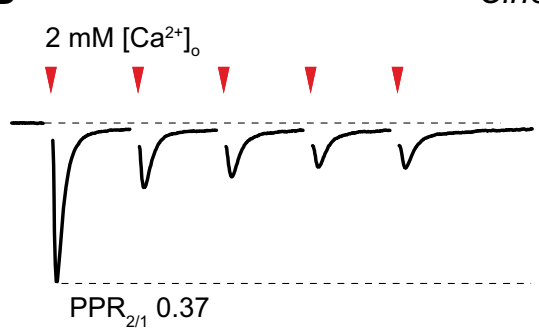

C

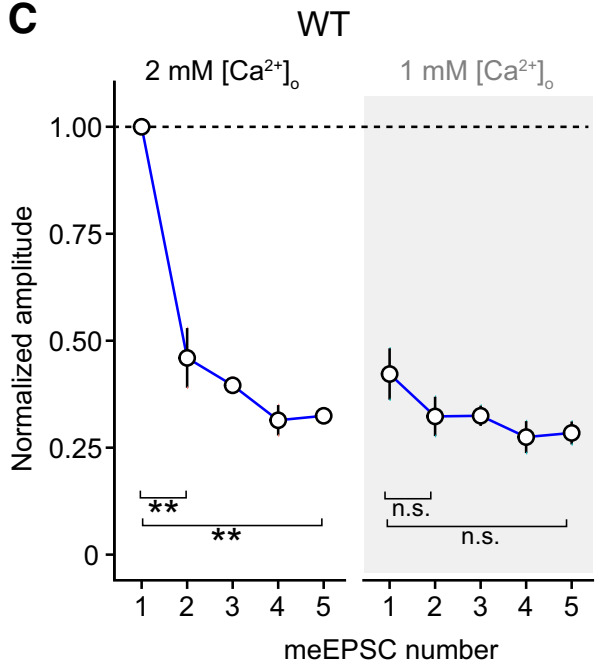

$C \ln 3^{\operatorname{sex} 1-6}$

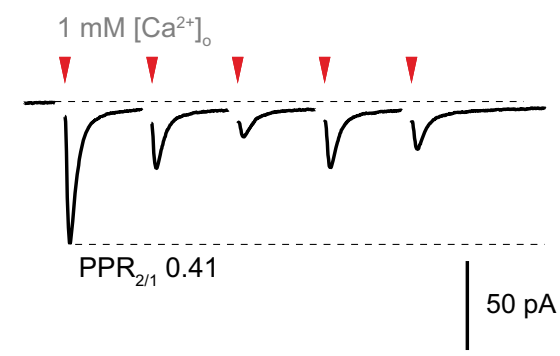

D $\quad C \ln 3^{\operatorname{Dex} 1-6}$

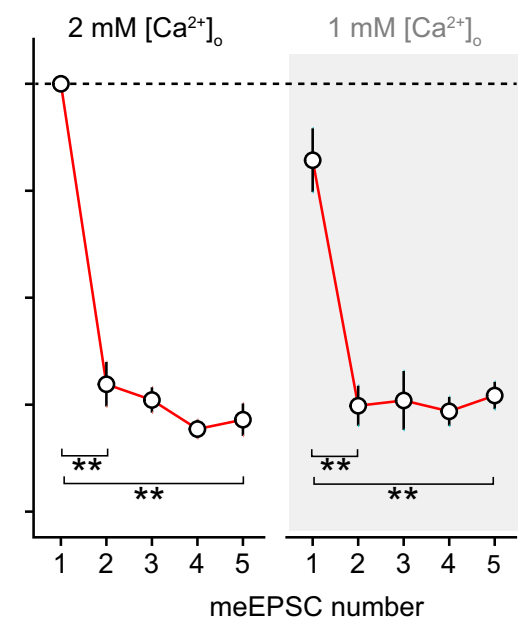

Figure 5. meEPSCs in granule cells in slices from wild-type (WT) and $C \ln 3^{\operatorname{Lex} 1-6}$ mice exhibit different patterns of short-term plasticity in low extracellular $\mathrm{Ca}^{2+}$. A, Averaged meEPSCs from a representative WT granule cell evoked during a five-pulse $100-\mathrm{Hz}$ train in the presence of 2 and $1 \mathrm{mM}$ extracellular $\mathrm{Ca}^{2+}(-70 \mathrm{mV} ; 428$ and 110 sweeps, respectively). Red arrowheads indicate timing of stimuli (stimulus artifacts are blanked). PPRs (meEPSC $2 / \mathrm{meEPSC}_{1}$ ) are indicated as PPR $2 / 1$. $\boldsymbol{B}$, Same as $\boldsymbol{A}$ but for a representative $C / n^{\mathrm{Aex} 1-6}$ granule cell (197 and 111 sweeps). C, Plots showing normalized meEPSC amplitude in WT granule cells during five-pulse trains in 2 and $1 \mathrm{mM} \mathrm{Ca}^{2+}$. Symbols denote mean and error bars SEM. $\boldsymbol{D}$, Plots (as in $\boldsymbol{C}$ ) but for $C / n 3^{\mathrm{sex} 1-6}$ granule cells (**p $<0.01$ and n.s., non-significant; paired Wilcoxon rank sum test with Holm's sequential Bonferroni correction for multiple comparisons).

$\mathrm{W}=14, p=0.59)$, but amplitudes of meEPSC $_{1}$ in $1 \mathrm{mM}$ $\mathrm{Ca}^{2+}$ (normalized to those of meEPSC 1 in $2 \mathrm{mM} \mathrm{Ca}^{2+}$ ) were different $(0.42 \pm 0.06$ and $0.82 \pm 0.07$ in wild type and $\mathrm{Cln}^{\mathrm{\Delta ex1-6}}$, respectively; $\mathrm{W}=2, p=0.0087$ ).

\section{Structural changes at mossy fiber-granule cell synapses in $C \ln 3^{\Delta e x 1-6}$ mice}

We next used 2D transmission electron microscopy to compare mossy fiber to granule cell synapses from $\mathrm{Cln} 3^{\operatorname{\Delta ex1-6}}$ and wild-type mice (P13). Mossy fiber rosettes were identified from their characteristic size and appearance (many small vesicles, and a large number of mitochondria; Xu-Friedman and Regehr, 2003; Rothman et al.,
2016), and the fact that the mossy fiber makes contact with a large number of granule cell dendrites.

Initial examination revealed no striking gross anatomic differences between $\mathrm{C} / n 3^{\Delta e x 1-6}$ and wild-type synapses (Fig. 6A,B). The average vesicle diameter was unchanged in $C / n 3^{\Delta e x 1-6}$ compared to wild type (mean vesicle diameter per mossy fiber terminal $33.5 \pm 0.5$ vs $32.2 \pm 0.5 \mathrm{~nm}$, $n=20$ and 19 terminals from three mice each; $\mathrm{W}=130$, $p=0.094$; Fig. $6 C$ ). We observed a high average density of vesicles within each mossy fiber terminal, comparable to the values of $118-170 \mu \mathrm{m}^{-2}$ reported by Rothman et al. (2016). However, the average density of vesicles per mossy fiber terminal was decreased in $C \ln 3^{\operatorname{sex} 1-6}$ mice, 

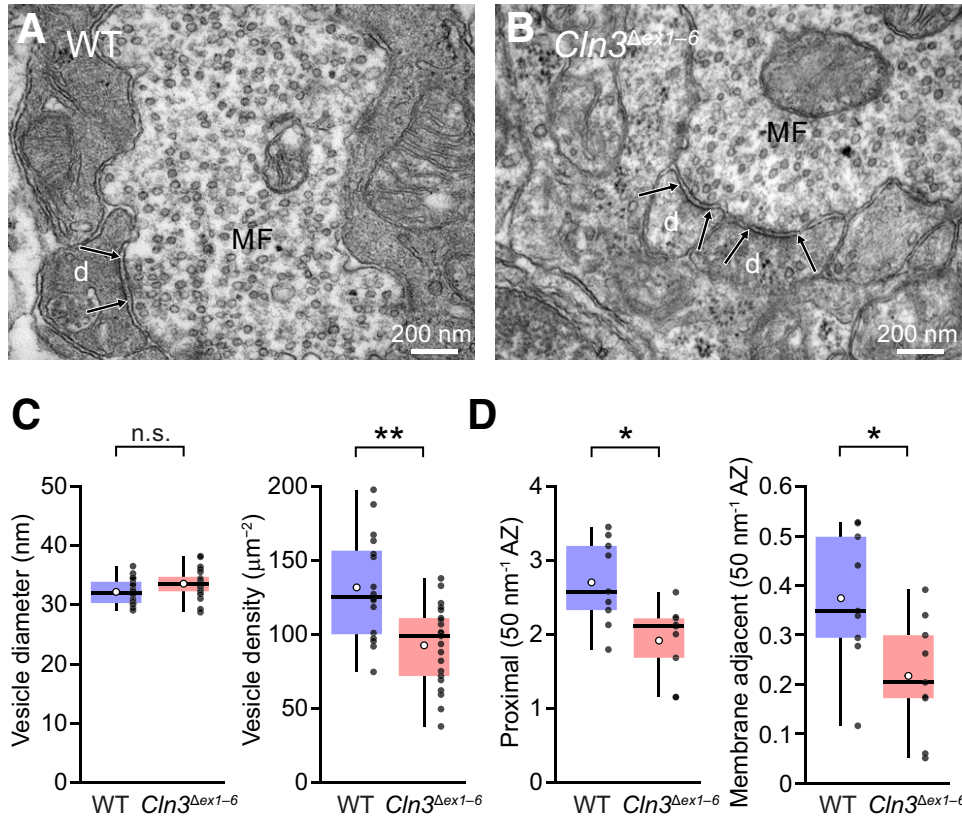

Figure 6. Reduced vesicle density in mossy fiber terminals of $C / n 3^{\Delta e x 1-6}$ mice. $\boldsymbol{A}$, Representative electron micrograph showing a wild-type (WT) mossy fiber terminal (MF) making a synaptic contact (delineated by arrows) with a granule cell dendrite (d). $\boldsymbol{B}$, Same as $\boldsymbol{A}$ but from a $\mathrm{Cln} 3^{\mathrm{Aex} 1-6}$ mouse. $\boldsymbol{C}$, Box-and-whisker plots (as in Fig. 1) showing the unaltered vesicle diameter and the reduced vesicle density. $\boldsymbol{D}$, Box-and-whisker plots (as in Fig. 1) showing the reduced number of vesicles proximal to active zones (AZ) and reduced number of membrane adjacent vesicles in MF terminals from $C / n 3^{\Delta e x 1-6}$ mice $(* * p<0.01$, $* p<0.05$; Wilcoxon rank sum test).

from $131.7 \pm 8.9$ to $92.6 \pm 6.0 \mu \mathrm{m}^{-2}(n=16$ and 21 terminals; $W=267, p=0.0025$; Fig. $6 C$ ). Additionally, when we determined the number of vesicles proximal to each active zone (within $100 \mathrm{~nm}$ ), the average number per $50-\mathrm{nm}$ length of active zone was reduced by $\sim 30 \%$ (from $2.70 \pm 0.19$ to $1.92 \pm 0.16, n=9$ terminals in each of three mice; $W=69, p=0.013$; Fig. $6 D$ ). When we considered only membrane adjacent vesicles (those within one vesicle radius of the presynaptic membrane), the number was reduced by $\sim 40 \%$ (from $1.24 \pm 0.16$ to $0.71 \pm$ 0.15 per active zone; $\mathrm{W}=67, p=0.022$ and from $0.37 \pm$ 0.04 to $0.22 \pm 0.04$ per $50 \mathrm{~nm}$ of active zone; $\mathrm{W}=65, p=$ 0.034 ; Fig. $6 D$ ). Of note, use of nested analysis (see Materials and Methods), rather than average measures per terminal, did not qualitatively alter the outcome. Thus, while vesicle diameter was unchanged, the overall vesicle density per terminal was slightly decreased, as was the average number of vesicles proximal to active zones and the number of membrane adjacent vesicles.

\section{Discussion}

We have examined granule cell AMPARs and cerebellar mossy fiber to granule cell synapses in the $C \ln 3^{\Delta e \times 1-6}$ mouse, a widely used model of juvenile Batten disease. Our main findings are as follows: First, GluA2 and GluA4 expression in cerebellar tissue from $C / n 3^{\Delta e \times 1-6}$ mice is unaltered. Second, AMPA-evoked currents in granule cells cultured from wild-type and $C / n 3^{\Delta e x 1-6}$ mice are not different. Third, the properties of synaptic AMPARs, their kinetics, voltage-dependence, and single-channel conductance, are unaltered. Fourth, loss of CLN3 leads to altered short-term plasticity in conditions of reduced extracellular
$\mathrm{Ca}^{2+}$. Fifth, in mossy fiber terminal from $\mathrm{C} / \mathrm{n}^{\mathrm{\Delta ex1-6}}$ mice the density of synaptic vesicles and their proximity to active zones is reduced. Thus, our experiments reveal unanticipated presynaptic changes but no evidence for altered postsynaptic AMPARs.

\section{Changes in synaptic transmission occur early in Cln $3^{\Delta e \times 1-6}$ mice}

Although the original studies of $\mathrm{C} / n 3^{\operatorname{\Delta ex} 1-6}$ mice reported accumulation of lysosomal storage material at approximately three months of age (Mitchison et al., 1999; Seigel et al., 2002) the mice were thought to lack clinical symptoms, even at 12 months (Mitchison et al., 1999). Subsequent studies identified deficits in motor coordination as early as P14 (Kovács et al., 2006), which were preceded by thinning of the cerebellar granule cell layer and Purkinje cell loss (Weimer et al., 2009). Our results suggest that there are indeed early changes in synaptic transmission in the cerebellum of $\mathrm{Cln} 3^{\Delta e \times 1-6}$ mice (P10-P15).

Our experiments do not allow us to conclude whether the observed changes are a direct consequence of CLN3 loss or represent secondary effects. In this regard, it is of note that extensive changes in gene expression and protein levels occur in $\mathrm{Cln} 3^{\mathrm{Dex} 1-6}$ mice (Brooks et al., 2003; Llavero Hurtado et al., 2017), potentially disrupting multiple neuronal pathways. Nevertheless, our findings in a mouse model of juvenile CLN3 disease complement molecular, structural, and functional studies in various animal models of infantile CLN1 disease (Virmani et al., 2005; Kim et al., 2008; Kielar et al., 2009), late infantile CLN6 disease (Kielar et al., 2009), congenital CLN10 disease (Koch et al., 2011), and late infantile CLN5 disease (Amorim 
et al., 2015), and suggest that early synaptic alteration is a characteristic feature of NCLs.

\section{No change in the rectification of AMPARs in Cln $3^{\Delta e \times 1-6}$ granule cells}

Previous studies reported increased AMPA-mediated neurotoxicity in dissociated granule cells and organotypic cultured cerebellar slices from one-week-old $\mathrm{C} / n 3^{\Delta e \times 1-6}$ mice (Kovács et al., 2006), and improved motor skills in one- to seven-month-old mice following AMPAR blockade (Kovács and Pearce, 2008; Kovács et al., 2011). These authors proposed an increase in the number of CP-AMPARs in Cln $3^{\Delta e \times 1-6}$ cerebellar granule cells, and abnormally increased AMPA receptor-mediated neurotransmission in the cerebellum. More recently, the same authors reported an increase in both total and surface GluA2 in acute cerebellar slices from one-month-old Cln3 ${ }^{\Delta e \times 1-6}$ mice, and proposed a decrease in the number of CP-AMPARs (Kovács et al., 2015). Our biochemical analysis and patch-clamp recordings do not support either of these proposals. We found no difference in the levels of GluA2 or GluA4 protein in cerebellar lysates of wild-type and $C / n 3^{\Delta e \times 1-6}$ mice. Importantly, we found the magnitude and $I-V$ relationships of AMPAR-mediated currents obtained in the presence of intracellular spermine to be similar in cultured cerebellar granule cells from wildtype and $C / n 3^{\Delta e x 1-6}$ mice. In both groups of mice, I-V relationships were linear, a feature characteristic of GluA2-containing calcium-impermeable AMPARs. Given that mEPSCs in $C / n 3^{\Delta e x 1-6}$ cells exhibited no detectable alteration in amplitude, rise time, decay time, rectification properties or underlying mean single-channel conductance, it seems highly likely that the number and composition of AMPARs at synapses was also unchanged. The reason for these disparities is unclear, but it should be noted that our studies were conducted using mice on a C57BL/6J background, whereas the work of Pearce and colleagues used mice on a 129S6/SvEv background. Importantly, while there are some background-specific differences in motor phenotype of these $\mathrm{C} / n 3^{\Delta e \times 1-6}$ strains, both exhibit clear motor deficits (Kovács and Pearce, 2015).

\section{Presynaptic changes at mossy fiber-granule cell synapses in $\mathrm{Cln}^{\mathrm{Dex1-6}}$ mice}

As with mEPSCs in cultured granule cells, the amplitude and kinetics of qEPSCs evoked at mossy fiber to granule cell synapses (in the presence of $\mathrm{Sr}^{2+}$ ) were unaffected by loss of CLN3. However, we found a marked decrease in the number of quanta released per stimulus in $\mathrm{Cln}^{\mathrm{Dex} 1-6}$ mice. This could indicate a reduction in the probability of release or simply the activation of fewer mossy fibers. Intriguingly, a recent report described increased hippocampal field excitatory post-synaptic potentials in $\mathrm{C} / n 3^{\Delta e \times 7 / 8}$ mice and suggested increased axonal excitability at the earliest age studied (one month; Burkovetskaya et al., 2017), tending to argue against the second of these possibilities. In a separate set of experiments in $2 \mathrm{mM} \mathrm{Ca}^{2+}$, we found the PPR of eEPSCs was not affected by loss of CLN3, suggesting no change in release probability. Thus, the effect of CLN3 loss may depend on the extracellular $\mathrm{Ca}^{2+}$ concentration.

In both wild-type and $\mathrm{C} / n 3^{\operatorname{sex1-6}}$ slices, we observed depression of eEPSC amplitudes during short trains of mossy fiber stimulation in the presence of standard extracellular divalent cations $\left(2 \mathrm{mM} \mathrm{Ca}{ }^{2+} / 1 \mathrm{mM} \mathrm{Mg}^{2+}\right)$. Surprisingly, when we reduced release probability by lowering extracellular $\mathrm{Ca}^{2+}\left(1 \mathrm{mM} \mathrm{Ca}{ }^{2+} / 2 \mathrm{mM} \mathrm{Mg}^{2+}\right)$, we observed loss of depression in wild-type cells (Nieus et al., 2006; Saviane and Silver, 2006) but not in C/n $3^{\Delta e x 1-6}$ cells. The fact that the loss of CLN3 appeared to have a functional impact on transmission only when extracellular $\mathrm{Ca}^{2+}$ was reduced suggests the possibility of an alteration in $\mathrm{Ca}^{2+}$ handling or sensing. Recent studies have indeed suggested that in both neurons (Warnock et al., 2013) and neuronal progenitor cells (Chandrachud et al., 2015) calcium handling is disrupted following loss of CLN3. This has been shown to result in the aberrant elevation of intracellular $\mathrm{Ca}^{2+}$ following $\mathrm{K}^{+}$-induced depolarization or moderate inhibition of the sarco/endoplasmic reticulum $\mathrm{Ca}^{2+}$-ATPase by thapsigargin. Whether altered $\mathrm{Ca}^{2+}$ handling in mossy fiber terminals could account for the differences in short term plasticity between $\mathrm{C} / n 3^{\Delta e \times 1-6}$ and wild-type mice is unclear.

\section{Ultrastructural changes at mossy fiber terminals in Cln $3^{\Delta e \times 1-6}$ mice}

Our 2D EM analyses revealed presynaptic structural changes in $C / n 3^{\Delta e x 1-6}$ mice, including a decrease in the vesicle density per mossy fiber terminal, a decrease in the number of vesicles proximal to active zones, and a decrease in membrane adjacent vesicles. Interestingly, broadly similar findings have been described in a different NCL. A reduction in vesicle number has been seen in cortical neurons from palmitoyl-protein thioesterase-1 knock-out mice $\left(\mathrm{Ppt1}^{-/-}\right)$, a model of infantile CLN1 disease (Virmani et al., 2005; Kim et al., 2008). This effect was linked with persistent membrane association of palmitoylated synaptic vesicle proteins preventing endocytosis. Conversely, in cathepsin D knock-out mice $\left(\mathrm{Ctsd}^{-1}\right)$, a model of congenital CLN10 disease, there is a reported increase at hippocampal CA1 synapses in the total vesicle number and in the number of docked vesicles (Koch et al., 2011). Thus, changes in the presynaptic vesicle pool may be a common feature of multiple NCLs. How, or if, the reduction we observe in synaptic vesicles of $C / n 3^{\Delta e \times 1-6}$ mice relates to previously described changes in intracellular vesicular trafficking of CLN3-deficient cells (Fossale et al., 2004; Metcalf et al., 2008; Tecedor et al., 2013; WavreShapton et al., 2015) remains to be determined. However, it is possible that the reduced vesicle numbers constitute a compensatory mechanism to overcome the tendency toward elevated release under physiologic conditions. This idea follows from our observation that in $1 \mathrm{mM} \mathrm{Ca}^{2+}$ normalized amplitudes of meEPSC in $C \ln 3^{\operatorname{sex} 1-6}$ mice were greater than those of wild-type mice. Of note, the reduced $\mathrm{Ca}^{2+}$ recordings are likely to reflect more accurately the situation in vivo, where the concentration of extracellular $\mathrm{Ca}^{2+}$ is thought to be closer to 1 rather than $2 \mathrm{mM}$ (Borst, 2010). 
Very recently, a paper was published which described disruption of supraspinal synaptic transmission in the $C / n 3^{\Delta e \times 1-6}$ mouse due to impaired presynaptic release, and proposed this as a causative mechanism in juvenile Batten disease (Grünewald et al., 2017). CLN3 loss was found to impair inhibitory PSCs or inhibitory synaptic transmission and to cause loss of GABAergic interneurons, in amygdala, hippocampus, and cerebellum. In addition, the authors reported a reduction in the amplitude of eEPSCs in both principal neurons of the lateral amygdala and granule cells of the dentate gyrus, no change in the amplitude of mEPSCs or spontaneous EPSCs, but a reduction in their frequency. Paired-pulse facilitation during stimulation of the lateral perforant path was also reduced. Overall, the findings were interpreted as reduction of excitatory and inhibitory inputs. Our results echo these observations in identifying presynaptic changes in $C / n 3^{\Delta e x 1-6}$ mice.

Irrespective of the precise mechanism underlying synaptic changes in $\mathrm{C} / n 3^{\Delta e x 1-6}$ mice (Cárcel-Trullols et al., 2015; Grünewald et al., 2017), our observations are potentially important in understanding the locus of early changes in juvenile Batten disease. While the recent study of Grünewald et al. (2017) examined synaptic function in symptomatic (14-month-old) $C / n 3^{\operatorname{sex} 1-6}$ mice, the synaptic changes we observed in two-week-old mice occurred in the presymptomatic phase of the disease, and are thus likely to reflect the initial causative changes. Previous functional studies focused primarily on an apparent selective increase in AMPAR function in cerebellar granule cells of $C / n 3^{\Delta e x 1-6}$ mice, and proposed a block of AMPARs as a potential therapeutic approach (Kovács et al., 2011). Importantly, our results argue strongly against any early change in postsynaptic AMPARs.

\section{References}

Abdul-Ghani MA, Valiante TA, Pennefather PS (1996) $\mathrm{Sr}^{2+}$ and quantal events at excitatory synapses between mouse hippocampal neurons in culture. J Physiol 495:113-125. CrossRef

Amorim IS, Mitchell NL, Palmer DN, Sawiak SJ, Mason R, Wishart TM, Gillingwater TH (2015) Molecular neuropathology of the synapse in sheep with CLN5 Batten disease. Brain Behav 5:e00401. CrossRef Medline

Autti T, Raininko R, Vanhanen SL, Santavuori P (1996) MRI of neuronal ceroid lipofuscinosis. I. Cranial MRI of 30 patients with juvenile neuronal ceroid lipofuscinosis. Neuroradiology 38:476482. Medline

Bates D, Mächler M, Bolker BM, Walker SC (2015) Fitting linear mixed-effects models using Ime4. J Stat Softw 67:1-48. CrossRef

Borst JG (2010) The low synaptic release probability in vivo. Trends Neurosci 33:259-266. CrossRef Medline

Bowie D, Mayer ML (1995) Inward rectification of both AMPA and kainate subtype glutamate receptors generated by polyaminemediated ion channel block. Neuron 15:453-462. Medline

Brooks Al, Chattopadhyay S, Mitchison HM, Nussbaum RL, Pearce DA (2003) Functional categorization of gene expression changes in the cerebellum of a Cln3-knockout mouse model for Batten disease. Mol Genet Metab 78:17-30. Medline

Burkovetskaya M, Karpuk N, Kielian T (2017) Age-dependent alterations in neuronal activity in the hippocampus and visual cortex in a mouse model of juvenile neuronal ceroid lipofuscinosis (CLN3). Neurobiol Dis 100:19-29. CrossRef

Burnashev N, Monyer H, Seeburg PH, Sakmann B (1992) Divalent ion permeability of AMPA receptor channels is dominated by the edited form of a single subunit. Neuron 8:189-198. Medline
Cárcel-Trullols J, Kovács AD, Pearce DA (2015) Cell biology of the NCL proteins: what they do and don't do. Biochim Biophys Acta 1852:2242-2255. CrossRef

Chabrol FP, Arenz A, Wiechert MT, Margrie TW, DiGregorio DA (2015) Synaptic diversity enables temporal coding of coincident multisensory inputs in single neurons. Nat Neurosci 18:718-727. CrossRef Medline

Chandrachud U, Walker MW, Simas AM, Heetveld S, Petcherski A, Klein M, Oh H, Wolf P, Zhao WN, Norton S, Haggarty SJ, LloydEvans E, Cotman SL (2015) Unbiased cell-based screening in a neuronal cell model of Batten disease highlights an interaction between $\mathrm{Ca}^{2+}$ homeostasis, autophagy, and CLN3 protein function. J Biol Chem 290:14361-14380. CrossRef

Chung C, Deák F, Kavalali ET (2008) Molecular substrates mediating lanthanide-evoked neurotransmitter release in central synapses. J Neurophysiol 100:2089-2100. CrossRef Medline

Corona JC, Tapia R (2007) $\mathrm{Ca}^{2+}$-permeable AMPA receptors and intracellular $\mathrm{Ca}^{2+}$ determine motoneuron vulnerability in rat spinal cord in vivo. Neuropharmacol 52:1219-1228. CrossRef

Cotman SL, Vrbanac V, Lebel LA, Lee RL, Johnson KA, Donahue LR, Teed AM, Antonellis K, Bronson RT, Lerner TJ, MacDonald ME (2002) $C / n 3^{\Delta e x 7 / 8}$ knock-in mice with the common JNCL mutation exhibit progressive neurologic disease that begins before birth. Hum Mol Genet 11:2709-2721. CrossRef

Cotman SL, Karaa A, Staropoli JF, Sims KB (2013) Neuronal ceroid lipofuscinosis: impact of recent genetic advances and expansion of the clinicopathologic spectrum. Curr Neurol Neurosci Rep 13: 366. CrossRef Medline

Cull-Candy SG, Howe JR, Ogden DC (1988) Noise and single channels activated by excitatory amino acids in rat cerebellar granule neurones. J Physiol 400:189-222. Medline

Cull-Candy S, Kelly L, Farrant M (2006) Regulation of $\mathrm{Ca}^{2+}$ permeable AMPA receptors: synaptic plasticity and beyond. Curr Opin Neurobiol 16:288-297. CrossRef Medline

Eccles JC, Ito M, Szentagothai J (1967) The cerebellum as a neuronal machine. Berlin: Springer.

Finn R, Kovács AD, Pearce DA (2011) Altered sensitivity of cerebellar granule cells to glutamate receptor overactivation in the $C / n 3^{\Delta e x 7 / 8_{-}}$ knock-in mouse model of juvenile neuronal ceroid lipofuscinosis. Neurochem Int 58:648-655. CrossRef

Follett PL, Rosenberg PA, Volpe JJ, Jensen FE (2000) NBQX attenuates excitotoxic injury in developing white matter. $J$ Neurosci 20:9235-9241. Medline

Fossale E, Wolf P, Espinola JA, Lubicz-Nawrocka T, Teed AM, Gao H, Rigamonti D, Cattaneo E, MacDonald ME, Cotman SL (2004) Membrane trafficking and mitochondrial abnormalities precede subunit $\mathrm{c}$ deposition in a cerebellar cell model of juvenile neuronal ceroid lipofuscinosis. BMC Neurosci 5:57. CrossRef

Geiger JR, Melcher T, Koh DS, Sakmann B, Seeburg PH, Jonas P, Monyer H (1995) Relative abundance of subunit mRNAs determines gating and $\mathrm{Ca}^{2+}$ permeability of AMPA receptors in principal neurons and interneurons in rat CNS. Neuron 15:193-204. Medline

Goda Y, Stevens CF (1994) Two components of transmitter release at a central synapse. Proc Natl Acad Sci USA 91:12942-12946. Medline

Grünewald B, Lange MD, Werner C, O'Leary A, Weishaupt A, Popp S, Pearce DA, Wiendl H, Reif A, Pape HC, Toyka KV, Sommer C, Geis C (2017) Defective synaptic transmission causes disease signs in a mouse model of juvenile neuronal ceroid lipofuscinosis. eLife 6:e28685. CrossRef

Haltia M (2003) The neuronal ceroid-lipofuscinoses. J Neuropathol Exp Neurol 62:1-13. Medline

Hartveit E, Veruki ML (2007) Studying properties of neurotransmitter receptors by non-stationary noise analysis of spontaneous postsynaptic currents and agonist-evoked responses in outside-out patches. Nat Protoc 2:434-448. CrossRef Medline

Huang CC, Sugino K, Shima Y, Guo C, Bai S, Mensh BD, Nelson SB, Hantman AW (2013) Convergence of pontine and proprioceptive 
streams onto multimodal cerebellar granule cells. eLife 2:e00400. CrossRef Medline

Kamboj SK, Swanson GT, Cull-Candy SG (1995) Intracellular spermine confers rectification on rat calcium-permeable AMPA and kainate receptors. J Physiol 486:297-303. CrossRef

Kaneda M, Farrant M, Cull-Candy SG (1995) Whole-cell and singlechannel currents activated by GABA and glycine in granule cells of the rat cerebellum. J Physiol 485:419-435. CrossRef

Kawahara Y, Kwak S (2005) Excitotoxicity and ALS: what is unique about the AMPA receptors expressed on spinal motor neurons? Amyotroph Lateral Scler Other Motor Neuron Disord 6:131-144. CrossRef Medline

Kielar C, Wishart TM, Palmer A, Dihanich S, Wong AM, Macauley SL, Chan CH, Sands MS, Pearce DA, Cooper JD, Gillingwater TH (2009) Molecular correlates of axonal and synaptic pathology in mouse models of Batten disease. Hum Mol Genet 18:4066-4080. CrossRef Medline

Kim SJ, Zhang Z, Sarkar C, Tsai PC, Lee YC, Dye L, Mukherjee AB (2008) Palmitoyl protein thioesterase-1 deficiency impairs synaptic vesicle recycling at nerve terminals, contributing to neuropathology in humans and mice. J Clin Invest 118:3075-3086. CrossRef Medline

Kitzmüller C, Haines RL, Codlin S, Cutler DF, Mole SE (2008) A function retained by the common mutant CLN3 protein is responsible for the late onset of juvenile neuronal ceroid lipofuscinosis. Hum Mol Genet 17:303-312. CrossRef Medline

Koh DS, Burnashev N, Jonas P (1995) Block of native $\mathrm{Ca}^{2+}$ permeable AMPA receptors in rat brain by intracellular polyamines generates double rectification. J Physiol 486:305-312. CrossRef

Koch S, Molchanova SM, Wright AK, Edwards A, Cooper JD, Taira T, Gillingwater TH, Tyynelä J (2011) Morphologic and functional correlates of synaptic pathology in the cathepsin D knockout mouse model of congenital neuronal ceroid lipofuscinosis. J Neuropathol Exp Neurol 70:1089-1096. CrossRef Medline

Kovács AD, Pearce DA (2008) Attenuation of AMPA receptor activity improves motor skills in a mouse model of juvenile Batten disease. Exp Neurol 209:288-291. CrossRef

Kovács AD, Pearce DA (2015) Finding the most appropriate mouse model of juvenile CLN3 (Batten) disease for therapeutic studies: the importance of genetic background and gender. Dis Model Mech 8:351-361. CrossRef Medline

Kovács AD, Weimer JM, Pearce DA (2006) Selectively increased sensitivity of cerebellar granule cells to AMPA receptor-mediated excitotoxicity in a mouse model of Batten disease. Neurobiol Dis 22:575-585. CrossRef

Kovács AD, Saje A, Wong A, Szénási G, Kiricsi P, Szabó E, Cooper JD, Pearce DA (2011) Temporary inhibition of AMPA receptors induces a prolonged improvement of motor performance in a mouse model of juvenile Batten disease. Neuropharmacol 60:405409. CrossRef

Kovács AD, Hof C, Pearce DA (2015) Abnormally increased surface expression of AMPA receptors in the cerebellum, cortex and striatum of $\mathrm{Cln3}^{-/-}$mice. Neurosci Lett 607:29-34. CrossRef Medline

Llavero Hurtado M, Fuller HR, Wong AMS, Eaton SL, Gillingwater TH, Pennetta G, Cooper JD, Wishart TM (2017) Proteomic mapping of differentially vulnerable pre-synaptic populations identifies regulators of neuronal stability in vivo. Sci Rep 7:12412. CrossRef Medline

Metcalf DJ, Calvi AA, Seaman M, Mitchison HM, Cutler DF (2008) Loss of the Batten disease gene CLN3 prevents exit from the TGN of the mannose 6-phosphate receptor. Traffic 9:1905-1914. CrossRef Medline

Mitchison HM, Bernard DJ, Greene ND, Cooper JD, Junaid MA, Pullarkat RK, de Vos N, Breuning MH, Owens JW, Mobley WC, Gardiner RM, Lake BD, Taschner PE, Nussbaum RL (1999) Targeted disruption of the $\mathrm{Cln} 3$ gene provides a mouse model for Batten disease. The Batten Mouse Model Consortium. Neurobiol Dis 6:321-334.
Mole SE, Cotman SL (2015) Genetics of the neuronal ceroid lipofuscinoses (Batten disease). Biochim Biophys Acta 1852:2237-2241. CrossRef

Molnár G, Rózsa M, Baka J, Holderith N, Barzó P, Nusser Z, Tamás $G$ (2016) Human pyramidal to interneuron synapses are mediated by multi-vesicular release and multiple docked vesicles. eLife 5:e18167.

Munroe PB, Mitchison HM, O'Rawe AM, Anderson JW, Boustany RM, Lerner TJ, Taschner PE, de Vos N, Breuning MH, Gardiner RM, Mole SE (1997) Spectrum of mutations in the Batten disease gene, CLN3. Am J Hum Genet 61:310-316. Medline

Nardocci N, Verga ML, Binelli S, Zorzi G, Angelini L, Bugiani O (1995) Neuronal ceroid-lipofuscinosis: a clinical and morphological study of 19 patients. Am J Med Genet 57:137-141. CrossRef

Nieus T, Sola E, Mapelli J, Saftenku E, Rossi P, D'Angelo E (2006) LTP regulates burst initiation and frequency at mossy fiber-granule cell synapses of rat cerebellum: experimental observations and theoretical predictions. J Neurophysiol 95:686-699. CrossRef

Nita DA, Mole SE, Minassian BA (2016) Neuronal ceroid lipofuscinoses. Epileptic Disord 18:73-88. CrossRef Medline

Noh KM, Yokota H, Mashiko T, Castillo PE, Zukin RS, Bennett MV (2005) Blockade of calcium-permeable AMPA receptors protects hippocampal neurons against global ischemia-induced death. Proc Natl Acad Sci USA 102:12230-12235. CrossRef Medline

Raininko R, Santavuori P, Heiskala H, Sainio K, Palo J (1990) CT findings in neuronal ceroid lipofuscinoses. Neuropediatrics 21:95101. CrossRef Medline

Rothman JS, Kocsis L, Herzog E, Nusser Z, Silver RA (2016) Physical determinants of vesicle mobility and supply at a central synapse. eLife 5:15133. CrossRef

Saviane C, Silver RA (2006) Fast vesicle reloading and a large pool sustain high bandwidth transmission at a central synapse. Nature 439:983-987. CrossRef Medline

Seehafer SS, Pearce DA (2006) You say lipofuscin, we say ceroid: defining autofluorescent storage material. Neurobiol Aging 27: 576-588. CrossRef Medline

Seigel GM, Lotery A, Kummer A, Bernard DJ, Greene ND, Turmaine M, Derksen T, Nussbaum RL, Davidson B, Wagner J, Mitchison HM (2002) Retinal pathology and function in a Cln3 knockout mouse model of juvenile neuronal ceroid lipofuscinosis (Batten disease). Mol Cell Neurosci 19:515-527. CrossRef

Tecedor L, Stein CS, Schultz ML, Farwanah H, Sandhoff K, Davidson BL (2013) CLN3 loss disturbs membrane microdomain properties and protein transport in brain endothelial cells. J Neurosci 33: 18065-18079. CrossRef Medline

The International Batten Disease Consortium (1995) Isolation of a novel gene underlying Batten disease, CLN3. Cell 82:949-957. CrossRef

Traynelis SF, Silver RA, Cull-Candy SG (1993) Estimated conductance of glutamate receptor channels activated during EPSCs at the cerebellar mossy fiber-granule cell synapse. Neuron 11:279289. Medline

Traynelis SF, Wollmuth LP, McBain CJ, Menniti FS, Vance KM, Ogden KK, Hansen KB, Yuan H, Myers SJ, Dingledine R (2010) Glutamate receptor ion channels: structure, regulation, and function. Pharmacol Rev 62:405-496. CrossRef Medline

Van Den Bosch L, Van Damme P, Bogaert E, Robberecht W (2006) The role of excitotoxicity in the pathogenesis of amyotrophic lateral sclerosis. Biochim Biophys Acta 1762:1068-1082. CrossRef Medline

Virmani T, Gupta P, Liu X, Kavalali ET, Hofmann SL (2005) Progressively reduced synaptic vesicle pool size in cultured neurons derived from neuronal ceroid lipofuscinosis-1 knockout mice. Neurobiol Dis 20:314-323. CrossRef Medline

Warnock A, Tan L, Li C, An Haack K, Narayan SB, Bennett MJ (2013) Amlodipine prevents apoptotic cell death by correction of elevated intracellular calcium in a primary neuronal model of Batten disease (CLN3 disease). Biochem Biophys Res Commun 436:645-649. CrossRef 
Wavre-Shapton ST, Calvi AA, Turmaine M, Seabra MC, Cutler DF, Futter CE, Mitchison HM (2015) Photoreceptor phagosome processing defects and disturbed autophagy in retinal pigment epithelium of $\mathrm{Cln} 3^{\Delta e x 1-6}$ mice modelling juvenile neuronal ceroid lipofuscinosis (Batten disease). Hum Mol Genet 24:7060-7074. CrossRef Medline

Weimer JM, Benedict JW, Getty AL, Pontikis CC, Lim MJ, Cooper JD, Pearce DA (2009) Cerebellar defects in a mouse model of juvenile neuronal ceroid lipofuscinosis. Brain Res 1266:93-107. CrossRef

Williams RE, Mole SE (2012) New nomenclature and classification scheme for the neuronal ceroid lipofuscinoses. Neurology 79:183191. CrossRef Medline

Xu-Friedman MA, Regehr WG (2003) Ultrastructural contributions to desensitization at cerebellar mossy fiber to granule cell synapses. J Neurosci 23:2182-2192. Medline 